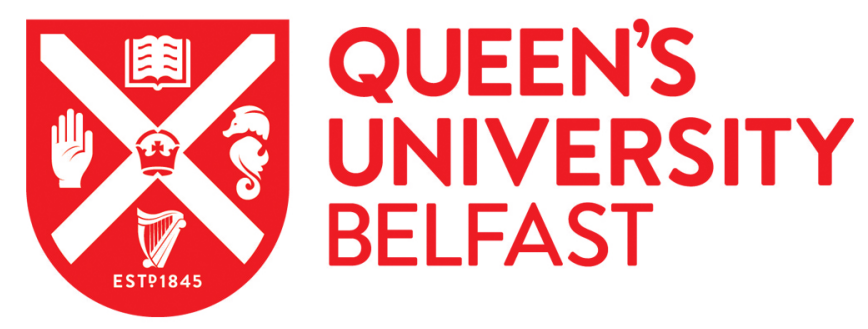

\title{
Sediment accumulation rates in subarctic lakes: insights into age- depth modeling from 22 dated lake records from the Northwest Territories, Canada.
}

Crann, C. A., Patterson, R. T., Macumber, A. L., Galloway, J. M., Roe, H. M., Blaauw, M., Swindles, G. T., \& Falck, H. (2015). Sediment accumulation rates in subarctic lakes: insights into age-depth modeling from 22 dated lake records from the Northwest Territories, Canada. Quaternary Geochronology, 27, 131-144. https://doi.org/10.1016/j.quageo.2015.02.001

Published in:

Quaternary Geochronology

Document Version:

Peer reviewed version

Queen's University Belfast - Research Portal:

Link to publication record in Queen's University Belfast Research Portal

\section{Publisher rights}

Copyright (C 2015 Published by Elsevier B.V.

This is the author's version of a work that was accepted for publication in Quaternary Geochronology. Changes resulting from the publishing process, such as peer review, editing, corrections, structural and other quality control mechanisms may not be reflected in this document. Changes may have been made to this work since it was submitted for publication. A definitive version was subsequently published in Quaternary Geochronology, vol 27, April 01 2015, doi:10.1016/j.quageo.2015.02.001

\section{General rights}

Copyright for the publications made accessible via the Queen's University Belfast Research Portal is retained by the author(s) and / or other copyright owners and it is a condition of accessing these publications that users recognise and abide by the legal requirements associated with these rights.

\section{Take down policy}

The Research Portal is Queen's institutional repository that provides access to Queen's research output. Every effort has been made to ensure that content in the Research Portal does not infringe any person's rights, or applicable UK laws. If you discover content in the Research Portal that you believe breaches copyright or violates any law, please contact openaccess@qub.ac.uk. 


\section{Accepted Manuscript}

Sediment accumulation rates in subarctic lakes: insights into age-depth modeling from 22 dated lake records from the Northwest Territories, Canada

Carley A. Crann, R. Timothy Patterson, Andrew L. Macumber, Jennifer M. Galloway, Helen M. Roe, Maarten Blaauw, Graeme T. Swindles, Hendrik Falck

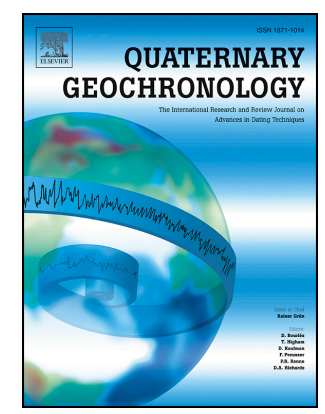

PII:

S1871-1014(15)00014-X

DOI:

10.1016/j.quageo.2015.02.001

Reference: QUAGEO 627

To appear in: Quaternary Geochronology

Received Date: 14 May 2014

Revised Date: 3 February 2015

Accepted Date: 4 February 2015

Please cite this article as: Crann, C.A., Patterson, R.T., Macumber, A.L., Galloway, J.M., Roe, H.M., Blaauw, M., Swindles, G.T., Falck, H., Sediment accumulation rates in subarctic lakes: insights into age-depth modeling from 22 dated lake records from the Northwest Territories, Canada, Quaternary Geochronology (2015), doi: 10.1016/j.quageo.2015.02.001.

This is a PDF file of an unedited manuscript that has been accepted for publication. As a service to our customers we are providing this early version of the manuscript. The manuscript will undergo copyediting, typesetting, and review of the resulting proof before it is published in its final form. Please note that during the production process errors may be discovered which could affect the content, and all legal disclaimers that apply to the journal pertain. 
1 Sediment accumulation rates in subarctic lakes: insights into age-depth modeling

2 from 22 dated lake records from the Northwest Territories, Canada

4 Carley A. Crann ${ }^{1}{ }^{\dagger}$, R. Timothy Patterson ${ }^{1}$, Andrew L. Macumber ${ }^{1}$, Jennifer M.

5 Galloway $^{2}$, Helen M. Roe ${ }^{3}$, Maarten Blaauw $^{3}$, Graeme T. Swindles ${ }^{4}$, Hendrik Falck ${ }^{5}$

6

$7 \quad{ }^{1}$ Department of Earth Sciences and Ottawa-Carleton Geoscience Centre, Carleton

8 University, Ottawa, Ontario, K1S 5B6, Canada

$9{ }^{2}$ Geological Survey of Canada Calgary/ Commission Géologique du Canada, Calgary,

10 Alberta, T2L 2A7, Canada

$11{ }^{3}$ School of Geography, Archaeology and Palaeoecology, Queen's University, Belfast,

12 Belfast, Northern Ireland, BT7 1NN, United Kingdom

$13{ }^{4}$ School of Geography, University of Leeds, Leeds, LS2 9JT, United Kingdom

$14{ }^{5}$ Northwest Territories Geoscience Office, Yellowknife, Northwest Territories, X1A 2R3,

15 Canada

16 *Corresponding author: ccrann@uottawa.ca 613-562-5800 x6864

$17{ }^{\dagger}$ Now: Department of Earth Sciences, University of Ottawa, Ottawa, Ontario, K1N 6N5,

18 Canada

19

20 RTP: Tim.Patterson@ carleton.ca

21 ALM: andrewmacumber@cmail.carleton.ca

22 JMG: jennifer.galloway@nrcan-rncan.gc.ca

23 HMR: h.roe@qub.ac.uk

24 MB: maarten.blaauw@ qub.ac.uk

25 GTS: g.t.swindles@leeds.ac.uk

26 HF: hendrik_falck@gov.nt.ca 


\section{Abstract}

32 Age-depth modeling using Bayesian statistics requires well-informed prior information

33 about the behavior of sediment accumulation. Here we present average sediment

34 accumulation rates (represented as deposition times, DT, in $\mathrm{yr} / \mathrm{cm}$ ) for lakes in an Arctic

35 setting, and we examine the variability across space (intra- and inter-lake) and time (late

36 Holocene). The dataset includes over 100 radiocarbon dates, primarily on bulk sediment,

37 from 22 sediment cores obtained from 18 lakes spanning the boreal to tundra ecotone

38 gradients in subarctic Canada. There are four to twenty-five radiocarbon dates per core,

39 depending on the length and character of the sediment records. Deposition times were

40 calculated at 100-year intervals from age-depth models constructed using the 'classical'

41 age-depth modeling software Clam. Lakes in boreal settings have the most rapid

42 accumulation (mean DT $20 \pm 10$ years), whereas lakes in tundra settings accumulate at

43 moderate (mean DT $70 \pm 10$ years) to very slow rates, $(>100 \mathrm{yr} / \mathrm{cm})$. Many of the age-

44 depth models demonstrate fluctuations in accumulation that coincide with lake evolution

45 and post-glacial climate change. Ten of our sediment cores yielded sediments as old as c.

$469,000 \mathrm{cal} \mathrm{BP}(\mathrm{BP}=$ years before $\mathrm{AD} 1950)$. From between c. 9,000 cal BP and c. 6,000

47 cal BP, sediment accumulation was relatively rapid (DT of 20 to $60 \mathrm{yr} / \mathrm{cm}$ ).

48 Accumulation slowed between c. 5,500 and c. 4,000 cal BP as vegetation expanded

49 northward in response to warming. A short period of rapid accumulation occurred near

$50 \quad 1,200 \mathrm{cal} \mathrm{BP}$ at three lakes. Our research will help inform priors in Bayesian age

51 modeling.

\section{Keywords}

53 Bayesian age-depth modeling, accumulation rate, deposition time, Bacon, Subarctic, 
54 Northwest Territories, paleolimnology

\section{1. Introduction}

56 Lake sediment accumulation rates vary across space and time (Lehman, 1975; Terasmaa,

57 2011). Characterization of the spatial trends in accumulation rate for a region and within

58 a lake basin is valuable for sample site selection in paleolimnological studies, as it is

59 often favorable to sample lakes with sufficiently high accumulation rates to achieve a

60 desirable temporal resolution in the data. Understanding the temporal variability and

61 timing of major shifts in accumulation rate as well as the causes of major accumulation

62 rate shifts for a region can be extremely valuable for deciding on levels in an age-depth

63 model that would benefit from additional radiocarbon dates. Such changes in

64 accumulation rate can be used to better understand the limnological system of study and

65 the impact of climate change on that system. Moreover, there are many examples where

66 changes in sediment accumulation rate have been linked to climatic change. For

67 example, in the Cathedral Mountains of British Columbia, the highest Holocene levels of

68 sediment yield are coincident with late Holocene ( 4,000 BP) climate cooling, reduced

69 catchment vegetation and increased terrestrial erosion (Evans and Slaymaker, 2004).

70 Similarly, in a crater lake in equatorial East Africa, Blaauw et al. (2011) found that cooler

71 climate conditions also resulted in reduced vegetation cover and increased terrestrial

72 erosion and allochtonous sediment input into the lake. Knowledge of accumulation rate

73 is also necessary for proxy-based reconstructions of mean fire return interval, rates of

74 vegetation change (Koff et al., 2000; Marlon et al., 2006), and carbon accumulation rate

75 studies (e.g. Charman et al. 2013), for example, that are only as good as the chronologies

76 they are based upon. 
78 The integration of sediment accumulation rate information into Bayesian age-depth

79 models as prior knowledge, or "priors" is particularly important for sections of an age-

80 depth model where the behavior of the model is uncertain (e.g. sparse data, age reversals,

81 age offsets, dates within a radiocarbon plateau). It can be a challenge, however, to

82 estimate the accumulation rate prior. Goring et al. (2012) provided a summary of

83 sediment accumulation rates from 152 lacustrine sites in the northeastern US/southeastern

84 Canada region and found that, in general, sediment accumulated with a DT of around 20

$85 \mathrm{yr} / \mathrm{cm}$. This result is fairly similar to the previous findings of Webb and Webb $(1988 ; 10$

$86 \mathrm{yr} / \mathrm{cm}$ ) for the same region. However, these estimates are too rapid for subarctic and

87 arctic lakes, where a short ice-free season and low availability of organic material relative

88 to more southern sites lead to slow annual sediment accumulation rates (e.g. Saulnier-

89 Talbot et al., 2009).

90

91 This paper expands upon the temperate lake research of Goring et al. (2012) and Webb

92 and Webb (1988). We examine Holocene accumulation rate data for 22 lacustrine sites

93 from a latitudinal gradient spanning boreal forest, treeline, and tundra settings in the

94 Northwest Territories, Canada. While this is a much smaller dataset than Webb and

95 Webb (1988) and Goring et al. (2012), it is significant given that it is logistically difficult

96 to obtain sediment records in arctic and subarctic regions due to the lack of infrastructure.

97 Goring et al. (2012) suggest that such regional datasets can provide important prior

98 knowledge to inform Bayesian (and other) age models.

99 
100 The age-depth models presented in this paper were constructed in support of an

101 interdisciplinary project aimed at better understanding the natural variability of climate

102 along the routed of the Tibbitt to Contowyto Winter Road (TCWR) in the central

103 Northwest Territories (Canada). Increased precision of age-depth models and increased

104 sampling resolution of proxy data from lake sediment cores have permitted higher

105 resolution characterization paleoclimate patterns (e.g., Galloway et al., 2010; Macumber

106 et al., 2012; Upiter et al., 2014).

107

\section{$108 \quad 2 . \quad$ Regional setting}

109 Lakes investigated in this study are located in the central Northwest Territories (Fig. 1) in

110 an area underlain by a portion of the Canadian Shield known as the Slave Craton. This

111 section of Archean crust is characterized by a depositional and volcanic history that has

112 been overprinted by multiple phases of deformation and intruded by granitoid plutons

113 (Bleeker, 2002). Major rock units include basement gneisses and metavolcanics,

114 metasedimentary rocks, and widespread gneissic-granitoid plutons (Padgham and Fyson,

115 1992; Helmstaedt, 2009). This bedrock geology lacks carbon-rich rocks such as

116 limestones or marl, and is unlikely to be a source of ${ }^{~}{ }^{14} \mathrm{C}$ dead' carbon, which can cause

117 radiocarbon dates to appear anomalously old. 


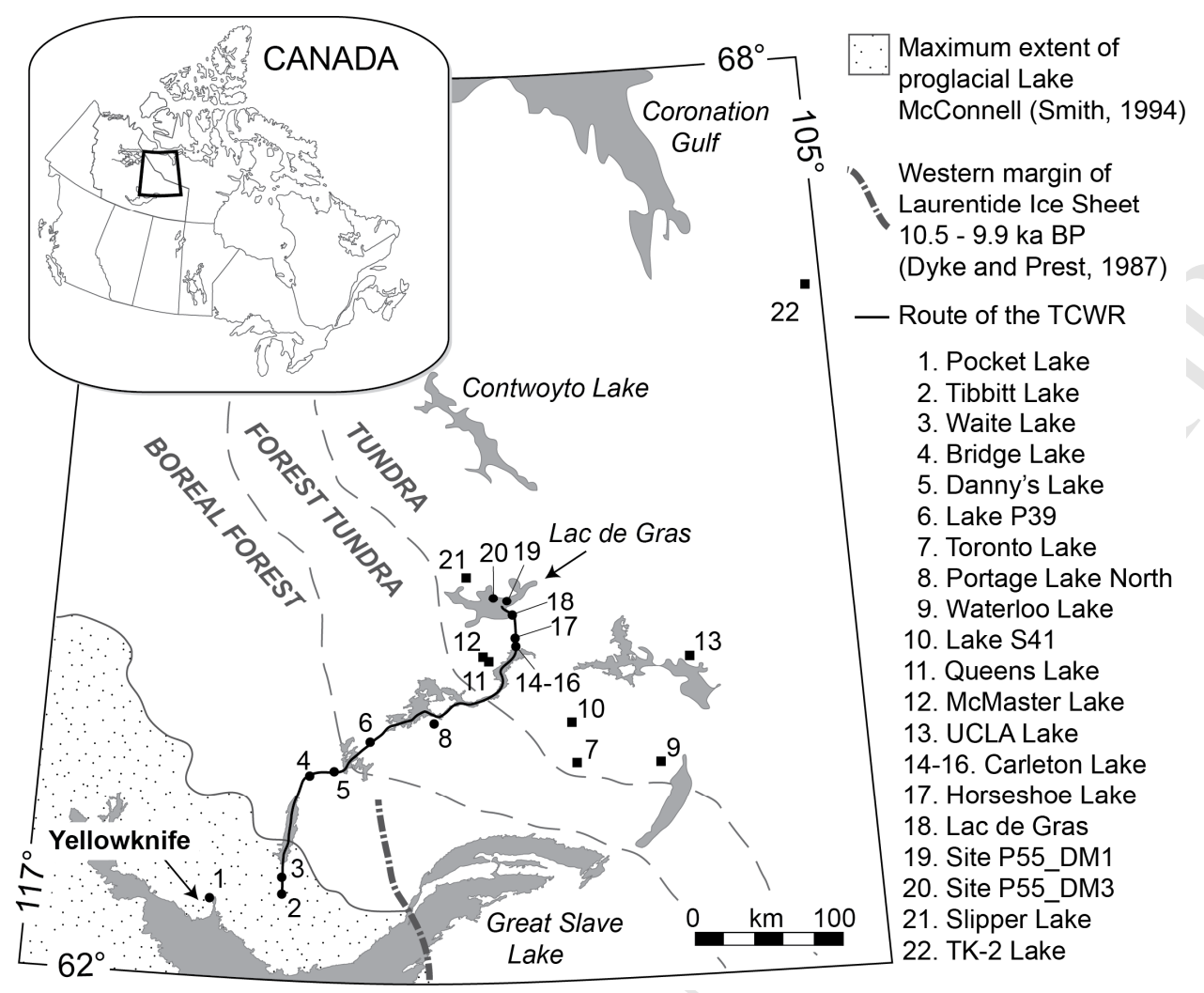

119 Figure 1. Map of the Northwest Territories showing the locations of core sites. Circles

120 are sites from the TCWR project, squares are sites from previously published work,

121 dashed lines show current boundaries between tundra, forest tundra, and boreal forest

122 ecozones, and the inset shows the location of the study area within Canada. References

123 for the previously published sites are given in Table 1. Two column image.

125 The Slave Craton has been isostatically uplifting since the retreat of the Laurentide

126 Glacier about 10,000-9,000 years ago (Dyke and Prest, 1987; Dyke et al., 2003).

127 Glacial-erosional processes have shaped the terrain, which is characterized by a gentle

128 relief of only a few tens of meters (Rampton, 2000). Where bedrock is not exposed, it

129 lies beneath deposits of till and glaciofluvial sediment of varying thickness. The action 
130 of glacial erosion and subglacial meltwater flow has resulted in a landscape with

131 abundant, often interconnected lakes. Figure 1 shows the approximate western margin of

132 the Laurentide Ice Sheet as it retreated toward the east, sometime between 10,500 and

1339900 years ago (Dyke and Prest, 1987) as well as the maximum extent of proglacial Lake

134 McConnell (Smith, 1994). Lake McConnell was the main proglacial lake in the region

135 following the retreat of the Laurentide Ice Sheet.

136

137 The present-day treeline runs NW/SE across the study area, roughly reflecting the polar

138 front (Fig. 1). The treeline is marked by the northern limits of the boreal forest (Fig. 2a),

139 where forest stands are open and lichen woodlands merge into areas of shrub tundra

140 (Galloway et al., 2010; Fig. 2b). Soils are poorly developed with discontinuous

141 permafrost south of the treeline, and continuous permafrost north of the treeline (Clayton

142 et al., 1977). Tundra vegetation is composed of lichens, mosses, sedges, grasses, and

143 diverse herbs (MacDonald et al., 2009). The vegetation cover and soils are often affected

144 by polygonal permafrost features (Fig. 2c), and are discontinuous on rocky substrates. 

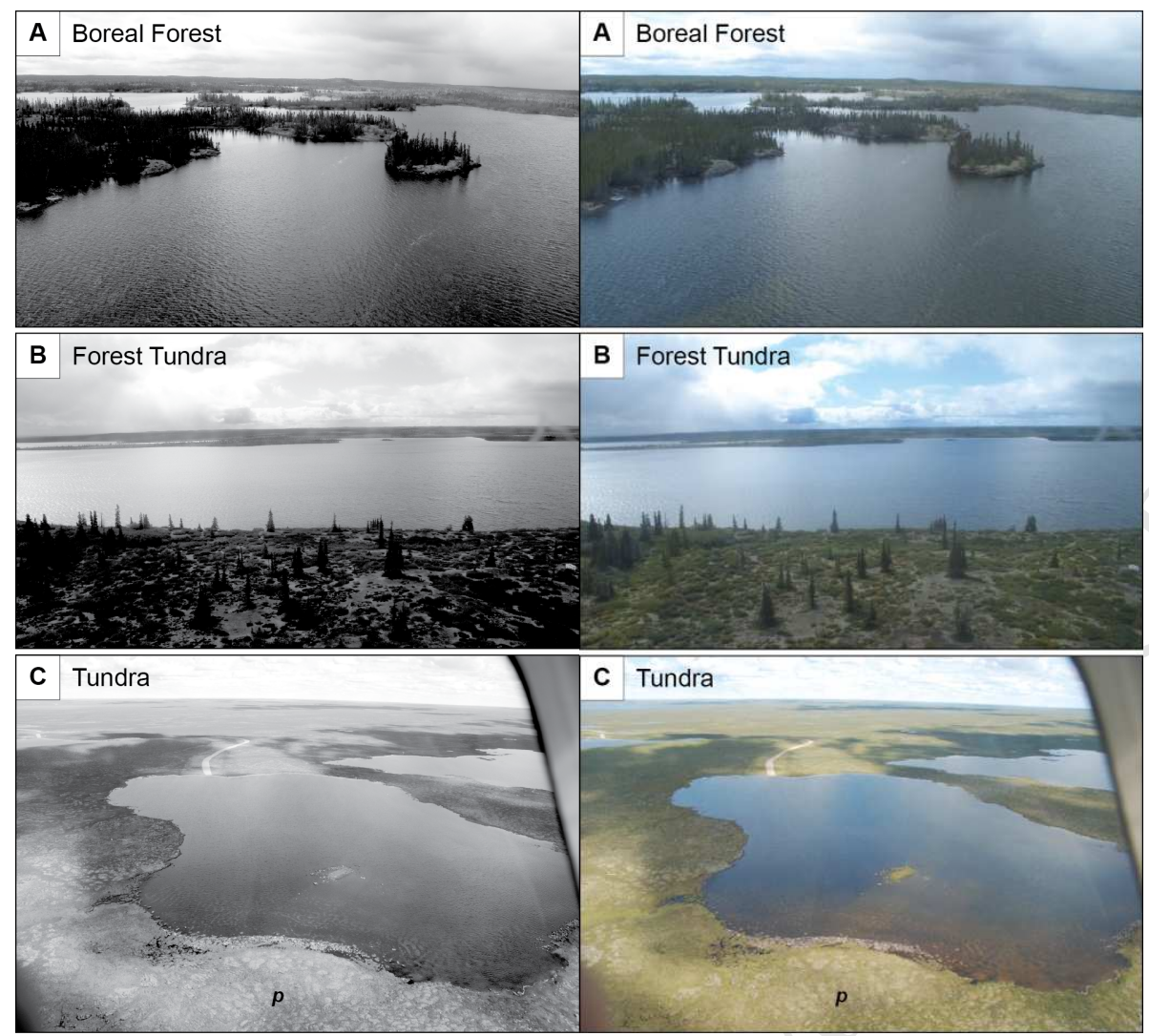

146 Figure 2. Images of the (a) boreal forest zone at Waite Lake, (b) forest tundra ecotone

147 near Portage Lake North (actually Mackay Lake, not mentioned in this paper), and (c)

148 tundra zone at Carleton Lake, where "p" shows an area with soil polygon development.

149 At Carleton Lake, the path of the TCWR can be seen exiting the lake to the north. One

150 column image. Colour version for web only. Black and white for print.

152 The climate of the region is subarctic continental, characterized by short summers and

153 long cold winters. Annual precipitation is low $(175-200 \mathrm{~mm})$ and mean daily January

154 temperatures range from $-17.5^{\circ} \mathrm{C}$ to $-27.5^{\circ} \mathrm{C}$, while mean daily July temperatures range

155 from $7.5^{\circ} \mathrm{C}$ to $17.5^{\circ} \mathrm{C}$. Lakes in the region are often ice-covered for much of the year,

156 with an average open-water period of only 90 days (Wedel et al., 1990). 
158 Broad-scale patterns of Holocene climate change in the study area have been identified

159 by proxy evidence from lake sediment cores from Toronto Lake (MacDonald et al., 1993;

160 Wolfe et al., 1996; Pienitz et al., 1999), Waterloo Lake (MacDonald et al., 1993), Lake

161 S41 (MacDonald et al., 2009), Queen's Lake (Moser and MacDonald, 1990; MacDonald

162 et al., 1993; Wolfe et al., 1996; Pienitz et al., 1999), McMaster Lake (Moser and

163 MacDonald 1990; MacDonald et al., 1993), UCLA Lake (Huang et al., 2004), Slipper

164 Lake (Rühland and Smol, 2005), and Lake TK-2 (Paul et al., 2010) (Fig. 1; Table 1).

165 Based on this body of previous work, three main stages of landscape development have

166 been inferred: (1) between deglaciation (c. 9,000 cal BP) and c. 6,000 cal BP, terrestrial

167 erosion decreased as vegetation developed from tundra to Betula-dominated shrub tundra,

168 and finally to spruce forest tundra (Huang et al., 2004; Sulphur et al., in prep) and

169 stabilized the landscape; (2) between c. 6,000 and c. 3,500 cal BP the treeline moved

170 north of its present location in response to climate warming (Moser and MacDonald,

171 1990; MacDonald et al., 1993), likely reflecting a northward retreat of the polar front

172 following the demise of the ice sheet in the middle Holocene (Huang et al., 2004); and (3)

173 between c. 3,000 cal BP to the present, there was a general trend towards climate cooling.

174 This resulted in an increase in birch-dominated shrub tundra in the more northerly sites

175 (UCLA lake; Huang et al., 2004). At the more southern locations, vegetation shifts

176 associated with climate change during the latest Holocene are also documented (change

177 c. 1,000 cal BP at Danny's Lake; Sulphur et al., in prep.).

179 Table 1. Coordinates and physical characteristics of the lakes used in this study.

180 Citations: (1) Moser and MacDonald, 1990; (2) MacDonald et al., 1993; (3) Edwards et 
181 al., 1996; (4) Wolfe et al., 1996; (5) Penitz et al., 1999; (6) Huang et al., 2004; (7)

182 Rühland and Smol, 2005; (8) MacDonald et al., 2009; (9) Paul et al., 2010; (10)

183 Galloway et al., 2010; (11) Macumber et al., 2012; (12) Upiter et al., 2014.

184 *TCWR JV = Tibbitt to Contwoyto Winter Road Joint Venture

\begin{tabular}{|c|c|c|c|c|c|c|c|}
\hline $\begin{array}{l}\text { Site } \\
\text { ID }\end{array}$ & Site name & $\begin{array}{l}\text { TCWR } \\
\text { JV* ID }\end{array}$ & Latitude & Longitude & $\begin{array}{l}\text { Surface } \\
\text { area (ha) }\end{array}$ & $\begin{array}{l}\text { Depth } \\
\text { (m) }\end{array}$ & Citation \\
\hline 1 & Pocket Lake & - & $62^{\circ} 30.540$ & $114^{\circ} 22.314$ & 6 & 3.5 & \\
\hline 2 & Tibbitt Lake & $\mathrm{P} 0$ & $62^{\circ} 32.800$ & $113^{\circ} 21.530$ & 300 & 6.72 & 10,11 \\
\hline 3 & Waite Lake & $\mathrm{P} 14-2$ & $62^{\circ} 50.987$ & $113^{\circ} 19.643$ & 100 & 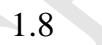 & 10,11 \\
\hline 4 & Bridge Lake & $\mathrm{P} 26$ & $63^{\circ} 23.297$ & $112^{\circ} 51.768$ & 119.5 & 4.5 & 11 \\
\hline 5 & Danny's Lake & P34 & $63^{\circ} 28.547$ & $112^{\circ} 32.250$ & 4.4 & 4.4 & 11 \\
\hline 6 & Lake P39 & P39 & $63^{\circ} 35.105$ & $112^{\circ} 18.436$ & 37.3 & 1.1 & 11 \\
\hline 7 & Toronto Lake & - & $63^{\circ} 25.800$ & $109^{\circ} 12.600$ & 10 & 6.75 & $2,4,5$ \\
\hline 8 & Portage Lake N & P47 & $63^{\circ} 44.538$ & $111^{\circ} 12.957$ & 194.9 & 4.85 & 11 \\
\hline 9 & Waterloo Lake & - & $63^{\circ} 26.400$ & $108^{\circ} 03.600$ & $?$ & $?$ & 2 \\
\hline 10 & Lake S41 & - & $63^{\circ} 43.110$ & $109^{\circ} 19.070$ & $<0.3$ & 4.4 & 8 \\
\hline 11 & Queens Lake & - & $64^{\circ} 07.000$ & $110^{\circ} 34.000$ & 50 & 4.5 & $1-5$ \\
\hline 12 & McMaster Lake & - & $64^{\circ} 08.000$ & $110^{\circ} 35.000$ & 12 & $8.0 ?$ & 1,2 \\
\hline 13 & UCLA Lake & - & $64^{\circ} 09.000$ & $107^{\circ} 49.000$ & 28 & 7.7 & 6 \\
\hline 14 & Carleton-1A & P49 & $64^{\circ} 15.571$ & $110^{\circ} 05.878$ & 29.8 & 15 & 11 \\
\hline 15 & Carleton-1B & P49 & $64^{\circ} 15.571$ & $110^{\circ} 05.878$ & 29.8 & 1.5 & 11,12 \\
\hline 16 & Carleton-2012 & P49 & $64^{\circ} 15.500$ & $110^{\circ} 05.928$ & 29.8 & 3.0 & \\
\hline 17 & Horseshoe Lake & P52 & $64^{\circ} 17.381$ & $110^{\circ} 03.701$ & 505 & 4.0 & 11 \\
\hline 18 & Lac de Gras & P55 & $64^{\circ} 25.794$ & $110^{\circ} 08.168$ & $\sim 57 \mathrm{k}$ & 4.0 & 11 \\
\hline 19 & Lac de Gras_DM1 & P55 & $64^{\circ} 30.393$ & $110^{\circ} 15.255$ & $\sim 57 \mathrm{k}$ & $?$ & \\
\hline 20 & Lac de Gras_DM3 & P55 & $64^{\circ} 33.723$ & $110^{\circ} 26.841$ & $\sim 57 \mathrm{k}$ & $?$ & \\
\hline 21 & Slipper Lake & - & $64^{\circ} 37.000$ & $110^{\circ} 50.000$ & 190 & 14.0 & 7 \\
\hline 22 & Lake TK-2 & - & $66^{\circ} 20.900$ & $104^{\circ} 56.750$ & 2.8 & $7.5 ?$ & 9 \\
\hline
\end{tabular}

186 3. Materials and methods

$187 \quad 3.1 \quad$ Core collection

188 The coordinates of each lake, as well as basic lake parameters (surface area, core depth,

189 inlets/outlets) for each site and the relevant references are summarized in Table 1. Data

190 from eight previously published paleolimnological studies located in the area have been

191 incorporated into the dataset to improve perspective on regional trends. The sediment

192 cores from these studies were collected using a modified Livingstone corer (Wright et al.,

193 1984), except the Slipper Lake core, which was collected using a modified KB gravity 
194 corer and a mini-Glew gravity corer (Glew, 1991; Glew et al., 2001).

195

196 Sampling sites were distributed across the boreal forest, forest-tundra, and tundra

197 ecozones. Coring typically took place during the winter when equipment could be set up

198 directly on the TCWR, thus limiting sites to lakes with winter road access. Water depth

199 was measured in the field using a fish finder (echo sounder). For five lakes, detailed

200 bathymetric profiles were provided by EBA Engineering Consultants Ltd. These profiles

201 were collected during a through-ice bathymetry survey using ground-penetrating radar

202 (GPR) towed behind a vehicle.

204 The 14 new cores were collected using 1.5-2.0 m long, 10-20 cm wide, freeze corers

205 (hollow, metal-faced corers filled with dry ice; Galloway et al., 2010; Macumber et al.,

206 2012). Freeze corers are ideal for the extraction of cores in unconsolidated and water-

207 saturated sediment as they capture sediment by in situ freezing (Lotter et al., 1997; Glew

208 et al., 2001; Kulbe and Niederreiter, 2003; Blass et al., 2007). In 2009, Tibbitt and Waite

209 lakes were cored using a single-sided freeze corer (Galloway et al., 2010). The

210 uppermost sediments from the Waite Lake coring site were unfortunately not recovered

211 as the freeze corer over-penetrated the sediment-water interface during sampling. A

212 Glew core (Glew, 1991) was collected in 2011 in an attempt to capture the missing

213 sediment-water interface. In 2010 a custom designed double-sided freeze corer was

214 deployed in addition to the single-faced corer, to increase the volume of sediment

215 obtained at a given site (Macumber et al., 2012). Freeze cores were sliced at millimeter-

216 scale resolution using a custom designed sledge microtome (Macumber et al., 2011). The 
217 highest sampling resolution previously reported previously reported for the region had

218 been half-centimeter intervals from the Slipper Lake (Rühland and Smol, 2005) and Lake

219 S41 cores (MacDonald et al., 2009).

$2213.2 \quad$ Chronology

222 With the exception of one twig date in each of the Waite Lake and Queen's Lake cores,

223 and four twig dates in the Lake TK-2 core, radiocarbon dates were obtained from bulk

224 sediment samples, as macrofossils were not encountered during screening. Samples were

225 pretreated with a standard acid wash to remove carbonate material, and unless otherwise

226 stated in Section 4, analyses were performed using the accelerator mass spectrometer

227 (AMS) at the ${ }^{14}$ Chrono Dating Laboratory at Queen's University Belfast. Radiocarbon

228 dates reported from previous work employed both conventional and AMS techniques.

229 All radiocarbon ages in were calibrated using either Clam (Blaauw, 2010) or Calib

230 software version 6.1.0 (Stuiver and Reimer, 1993); both programs used the IntCal09

231 calibration curve (Reimer et al., 2009). Radiocarbon ages younger than AD1950 were

232 calibrated in CALIBomb (Reimer et al., 2004) with the NH_zone1.14c dataset (Hua and

233 Barbetti, 2004). For the Holocene dates used in this study, the differences between the

234 IntCal09 and IntCal13 (Reimer et al., 2013) calibration curves, as well as between the

2352004 and 2013 (Hua et al., 2013) postbomb curves are negligible (for our purposes), but

236 we would recommend using the newest curves in future studies. Dates from a ${ }^{210} \mathrm{~Pb}$

237 profile from Slipper Lake were also incorporated into the dataset (Rühland and Smol,

238 2005). The Pocket Lake core contains a visible tephra layer, which was geochemically

239 confirmed to as part of the White River Ash deposit (Crann et al., in prep). This horizon 
240 will be used in future studies to further constrain the age-depth model. The core from

241 nearby Bridge Lake was analyzed for both visible and cryptotephra, but was unsuccessful

242 in finding evidence for deposition of the White River Ash.

$2443.3 \quad$ Classical age-depth modeling with Clam

245 Smooth spline age-depth models were constructed for sediment cores obtained from the

246 TCWR and previously published studies using the 'classical' age-depth modeling

247 software Clam (Blaauw, 2010, R statistical software package) and the IntCal09

248 calibration curve (Reimer et al., 2009). The year the core was collected was added as the

249 age of the sediment-water interface with an error of \pm 5 years. The smoothing parameter,

250 which controls how sharply the model will curve toward radiocarbon dates, was

251 increased from the default value of 0.3 to 0.7 for the Danny's Lake model and to 0.5 for

252 the Waite Lake model in order to increase smoothness of the models through the large

253 number of radiocarbon dates. Otherwise, Clam's default smoothing parameter of 0.3 was

254 employed. The core from Lake P39 had only three non-outlying (see next paragraph)

255 dated horizons so the model was constructed using a linear regression. For Slipper Lake,

256 the three uppermost non-interpolated ${ }^{210} \mathrm{~Pb}$ dates were included in the model.

258 For cores with low dating resolution (typically less than five radiocarbon dates or less

259 than one radiocarbon date per thousand years), suspected outliers were removed on an ad

260 hoc basis when a radiocarbon date either created a clear age reversal in the model or an

261 anomalous shift in accumulation rate that could not be supported by sedimentological

262 evidence (visible colour change from grey clay to dark green-brown sediment). We also 
263 took into account the regional trends in sediment accumulation rate to aid with outlier

264 identification. For example, many age-depth models show a pronounced decrease in

265 accumulation rate after about 6,000 or 5,000 cal BP.

267 The Danny's Lake core is $115 \mathrm{~cm}$ long and has a few age reversals among the 25 -

268 radiocarbon dates. A Bayesian outlier analysis was performed using the general outlier

269 model (Bronk Ramsey, 2009a) on a sequence in OxCal version 4.1 (Bronk Ramsey,

270 2009b). This model assumes that the dates are ordered chronologically (dates further

271 down having older ages) and that outliers are in the calendar time dimension and

272 distributed according to a Student- $t$ distribution with 5 degrees of freedom (Christen,

273 1994; Bronk Ramsey, 2009a). Each radiocarbon date was assigned a 5\% prior

274 probability of being an outlier. The first outlier analysis identified all three dates at the

275 bottom of the core as outliers so we increased the prior probability of UBA-16439 to

$27610 \%$, as this date created the largest age reversal. A subsequent outlier analysis still

277 identified the two bottommost dates as outliers and it was unclear as to which was more

278 likely to be an outlier. We then examined the age-depth models from other lakes and

279 from previous studies for clues to resolve this problem. As many of the other models

280 support a higher accumulation rate prior to about $6000 \mathrm{cal} \mathrm{BP}$ we used this information to

281 increase the prior probability of UBA-17932 being an outlier to $10 \%$. In Section 5, we

282 show how the Bayesian software Bacon produces age models without performing a

283 separate, formal outlier analysis.

284

$2853.4 \quad$ Estimation of deposition time (DT) 
286 An estimate of DT ( $\mathrm{yr} / \mathrm{cm}$, inverse of accumulation rate) is required as a priori

287 information to generate age-depth models using the Bayesian software Bacon (Blaauw

288 and Christen, 2011). This estimate can be based on prior knowledge obtained from

289 previously built age-depth models from lakes in the region (Goring et al., 2012). Here we

290 generate a summary for the region using the age-depth models constructed in Clam to

291 calculate the DT at 100-year intervals for each model. It should be noted that the

292 intention of the summary is to produce initial estimates of DT for age-depth modeling

293 and the data has not undergone a rigorous statistical analysis. The DT between the

294 uppermost non-outlying date and the date used to model the surface age were not

295 included in graphing the accumulation rates because: (1) there is potential uncertainty

296 with the assumption that the age of the sediment-water interface is indeed the year that

297 the core was collected; and (2) high water content in the uppermost sediments can lead to

298 an anomalously rapid DT. Webb and Webb (1988) assumed 50\% compaction in

299 sediments below the uppermost 5 to $10 \mathrm{~cm}$ of the sediment column based on dry

300 weight/wet weight ratios, yet they found that the accumulation rates were still higher

301 during the historic period. Because dry weight/wet weight data has not been collected for

302 this study, the effect of compaction and dewatering is not taken into account in graphing

303 the DT. P39 and Slipper lake cores lacked sufficient chronological control and were

304 omitted from the DT compilation dataset.

305

$306 \quad$ 4. Results

307 The radiocarbon dates from all sites included in this study, along with the results from the

308 outlier analysis, are summarized in Table 2. The age-depth models constructed using 
309 Clam have been grouped into three categories (Fig. 3). The first category, rapid sediment

310 accumulation rate lakes, contains five age-depth models that stand out from the rest.

311 Deposition times in this category do not tend to exceed $50 \mathrm{yr} / \mathrm{cm}$, and the average DT

312 (rounded to the nearest $10=20 \mathrm{yr} / \mathrm{cm}$ ) is on par with lakes in the Great Lakes region

313 (Goring et al., 2012). The other two categories, moderate and slow sediment

314 accumulation rate lakes, are not so easily distinguished. Accumulation rates for age-

315 depth models in both categories fluctuate, but moderate sediment-rate accumulating sites

316 tend to fluctuate at more subtle amplitudes (DT of around $50 \mathrm{yr} / \mathrm{cm}$ ) and do not often

317 exceed a DT of $100 \mathrm{yr} / \mathrm{cm}$. Sites with overall slow accumulation rates fluctuate with DT

318 amplitudes up to $150 \mathrm{yr} / \mathrm{cm}$, and tend to be in excess of $100 \mathrm{yr} / \mathrm{cm}$.

320 Detailed results for each category are given in Sections 4.1-4.3. Because these results are

321 intended to yield insight into the spatial and temporal variability in accumulation rates in

322 high latitude lakes and to give estimates of DT that can be used as prior information in

323 Bayesian age-depth modeling with Bacon, DTs are rounded to the nearest $10 \mathrm{yr} / \mathrm{cm}$.

325 Table 2. Radiocarbon ages from all sites, calibrated with the IntCal09 calibration curve

326 (Reimer et al., 2009) using either Calib software version 6.1.0 (Stuiver and Reimer, 1993)

327 or Clam (Blaauw, 2010). The radiocarbon ages younger than AD1950 (italics) were

328 calibrated in CALIBomb (Reimer et al., 2004) with the NH_zone 1.14c dataset (Hua and

329 Barbetti, 2004). The year the core was collected is included as it was used to model the

330 age of the sediment-water interface in the Clam age-depth models. Dates identified as

331 outliers are shown in bold and radiocarbon dates younger than AD1950 are in italics. 


\begin{tabular}{|c|c|c|c|c|c|c|}
\hline Lake information & Lab ID & Method & $\begin{array}{l}\text { Depth } \\
(\mathrm{cm})\end{array}$ & $\begin{array}{l}{ }^{14} \mathrm{C} \text { age (BP) } \\
\pm 1 \sigma\end{array}$ & $\begin{array}{l}\text { Material } \\
\text { dated }\end{array}$ & $\begin{array}{l}\text { Cal BP } \pm \\
2 \sigma\end{array}$ \\
\hline Pocket Lake & UBA-20676 & AMS & $10-10.5$ & $362 \pm 27$ & Bulk & $310-414$ \\
\hline collected in 2012 & UBA-22350 & AMS & $20-20.5$ & $731 \pm 31$ & Bulk & $653-727$ \\
\hline \multirow[t]{6}{*}{ Freeze core $\left(2 F \_F 1\right)$} & UBA-20679 & AMS & $52-52.5$ & $1335 \pm 25$ & Bulk & $1286-1383$ \\
\hline & UBA-22351 & AMS & $57-57.5$ & $1394 \pm 30$ & Bulk & $1279-1348$ \\
\hline & UBA-22352 & AMS & $70-70.5$ & $1725 \pm 31$ & Bulk & $1556-1708$ \\
\hline & UBA-20677 & AMS & $90-90.5$ & $2501 \pm 30$ & Bulk & $2443-2559$ \\
\hline & UBA-22353 & AMS & $110-110.5$ & $1516 \pm 35$ & Bulk & 1333-1518 \\
\hline & UBA-20678 & AMS & $128.5-129$ & $2966 \pm 26$ & Bulk & 2916-3016 \\
\hline Tibbitt Lake (P0) & UBA-17353 & AMS & $20-21$ & $67 \pm 22$ & Bulk & $(-4)-255$ \\
\hline collected in 2009 & UBA-17354 & AMS & $40-41$ & $1409 \pm 20$ & Bulk & $1292-1343$ \\
\hline \multirow[t]{2}{*}{ Freeze core (1FR) } & UBA-17355 & AMS & $80-81$ & $2046 \pm 26$ & Bulk & $1930-2111$ \\
\hline & Beta-257687 & AMS & $138-138.5$ & $2390 \pm 40$ & Bulk & $2338-2696$ \\
\hline Waite Lake (P14-2) & $U B A-18968$ & $A M S$ & $17-17.5$ & $1.0562 \pm 0.003$ & Bulk & AD1956-1957 \\
\hline collected in 2010 & UBA-18969 & AMS & $27-27.5$ & $309 \pm 22$ & Bulk & $304-455$ \\
\hline Glew core & UBA-18970 & AMS & $37-37.5$ & $556 \pm 26$ & Bulk & $522-637$ \\
\hline Waite Lake (P14-2) & UBA-18474 & AMS & 0 & $1084 \pm 41$ & Bulk & $927-1066$ \\
\hline collected in 2009 & UBA-16433 & AMS & 16.9 & $995 \pm 24$ & Bulk & 800-961 \\
\hline \multirow[t]{8}{*}{ Freeze core (1FR) } & UBA-16434 & AMS & 29.1 & $1129 \pm 22$ & Bulk & $965-1076$ \\
\hline & UBA-16435 & AMS & 43.2 & $1455 \pm 23$ & Bulk & $1304-1384$ \\
\hline & UBA-16436 & AMS & 57.8 & $1519 \pm 22$ & Bulk & $1345-1514$ \\
\hline & Beta-257686 & AMS & 66.3 & $1520 \pm 40$ & Bulk & $1333-1520$ \\
\hline & UBA-15638 & AMS & 109.7 & $2107 \pm 29$ & Twig & $1997-2149$ \\
\hline & Beta-257688 & AMS & 154 & $2580 \pm 40$ & Bulk & $2498-2769$ \\
\hline & Beta-257689 & AMS & 185 & $2920 \pm 40$ & Bulk & $2955-3210$ \\
\hline & Beta-257690 & AMS & 205.1 & $3460 \pm 40$ & Bulk & $3633-3838$ \\
\hline \multirow{2}{*}{$\begin{array}{l}\text { Bridge Lake (P26-1) } \\
\text { collected in } 2010\end{array}$} & UBA-18964 & AMS & $6.5-7$ & $28 \pm 23$ & Bulk & $(-4)-244$ \\
\hline & UBA-22873 & AMS & $12.5-13$ & $694 \pm 26$ & Bulk & $565-683$ \\
\hline \multirow[t]{8}{*}{ Freeze core $\left(2 F_{-} F 2\right)$} & UBA-18965 & AMS & $18-18.5$ & $1883 \pm 23$ & Bulk & $1736-1882$ \\
\hline & UBA-22874 & AMS & $24.5-25$ & $3782 \pm 30$ & Bulk & $4082-4246$ \\
\hline & UBA-22875 & AMS & $30.5-31$ & $4730 \pm 30$ & Bulk & $5326-5583$ \\
\hline & UBA-22876 & AMS & $34.5-35$ & $5487 \pm 31$ & Bulk & $6210-6322$ \\
\hline & UBA-18966 & AMS & $41.5-42$ & $5816 \pm 42$ & Bulk & $6501-6727$ \\
\hline & UBA-22877 & AMS & $50.5-51$ & $6184 \pm 32$ & Bulk & $6977-7172$ \\
\hline & UBA-18967 & AMS & $59.5-60$ & $6762 \pm 32$ & Bulk & $7576-7667$ \\
\hline & UBA-22878 & AMS & $64-64.5$ & $7025 \pm 34$ & Bulk & 7788-7941 \\
\hline \multirow{9}{*}{$\begin{array}{l}\text { Danny's Lake (P34-2) } \\
\text { collected in } 2010 \\
\text { Freeze core }\left(2 F_{-} F 2\right)\end{array}$} & UBA-17359 & AMS & 5.7 & $693 \pm 21$ & Bulk & $567-679$ \\
\hline & UBA-17360 & AMS & 10.2 & $855 \pm 23$ & Bulk & $695-795$ \\
\hline & UBA-16543 & AMS & $15-15.5$ & $1329 \pm 23$ & Bulk & 1184-1299 \\
\hline & UBA-17361 & AMS & 21.9 & $1617 \pm 25$ & Bulk & $1416-1556$ \\
\hline & UBA-17431 & AMS & 27.8 & $1659 \pm 21$ & Bulk & $1521-1615$ \\
\hline & UBA-16544 & AMS & 32.6 & $1916 \pm 25$ & Bulk & 1818-1904 \\
\hline & UBA-20377 & AMS & 33.5 & $2071 \pm 24$ & Bulk & $1987-2120$ \\
\hline & UBA-20378 & AMS & 34.2 & $2159 \pm 24$ & Bulk & $2061-2305$ \\
\hline & UBA-17929 & AMS & 34.5 & $2257 \pm 26$ & Bulk & $2158-2343$ \\
\hline
\end{tabular}




\begin{tabular}{|c|c|c|c|c|c|c|}
\hline \multirow[t]{17}{*}{ Lake information } & Lab ID & Method & $\begin{array}{l}\text { Depth } \\
\text { (cm) }\end{array}$ & $\begin{array}{l}{ }^{14} \mathrm{C} \text { age (BP) } \\
\pm 1 \sigma\end{array}$ & $\begin{array}{l}\text { Material } \\
\text { dated }\end{array}$ & $\begin{array}{l}\text { Cal BP } \pm \\
2 \sigma\end{array}$ \\
\hline & UBA-20376 & AMS & 35.3 & $2073 \pm 28$ & Bulk & 1986-2124 \\
\hline & UBA-20375 & AMS & 36.8 & $2248 \pm 25$ & Bulk & $2158-2339$ \\
\hline & UBA-17432 & AMS & 37.6 & $2659 \pm 32$ & Bulk & 2742-2884 \\
\hline & UBA-20374 & AMS & 38.4 & $2392 \pm 25$ & Bulk & $2345-2488$ \\
\hline & UBA-20373 & AMS & 39.3 & $2448 \pm 33$ & Bulk & $2358-2702$ \\
\hline & UBA-17930 & AMS & 40.4 & $2549 \pm 26$ & Bulk & $2503-2748$ \\
\hline & UBA-20371 & AMS & 41.4 & $2554 \pm 28$ & Bulk & $2503-2750$ \\
\hline & UBA-20372 & AMS & 43.3 & $4863 \pm 29$ & Bulk & $5583-5652$ \\
\hline & UBA-16545 & AMS & $45-45.5$ & $2912 \pm 24$ & Bulk & 2964-3157 \\
\hline & UBA-16546 & AMS & 56.9 & $3604 \pm 25$ & Bulk & $3845-3975$ \\
\hline & UBA-16547 & AMS & 70.1 & $5039 \pm 51$ & Bulk & $5661-5903$ \\
\hline & UBA-16548 & AMS & $85-85.5$ & $5834 \pm 29$ & Bulk & $6560-6733$ \\
\hline & UBA-17931 & AMS & 89.5 & $6231 \pm 34$ & Bulk & $7016-7253$ \\
\hline & UBA-16439 & AMS & 95.5 & $8112 \pm 32$ & Bulk & 8997-9125 \\
\hline & UBA-17932 & AMS & 99.1 & $7623 \pm 38$ & Bulk & 8370-8518 \\
\hline & UBA-16440 & AMS & 113.6 & $7450 \pm 30$ & Bulk & $8191-8346$ \\
\hline \multirow{3}{*}{$\begin{array}{l}\text { P39-1A } \\
\text { collected in } 2010 \\
\text { Freeze core }\left(2 F_{-} F 1\right)\end{array}$} & UBA-17344 & AMS & $10-10.5$ & $3597 \pm 26$ & Bulk & $3840-3973$ \\
\hline & UBA-17345 & AMS & $19-19.5$ & $3701 \pm 24$ & Bulk & $3974-4144$ \\
\hline & UBA-17346 & AMS & $29-29.5$ & $5385 \pm 35$ & Bulk & $6018-6284$ \\
\hline \multirow{4}{*}{$\begin{array}{l}\text { Toronto Lake } \\
\text { collected in } 1987 \\
\text { Livingstone core }\end{array}$} & Beta-49705 & conv. & $35-50$ & $1760 \pm 90$ & Bulk & $1421-1887$ \\
\hline & Beta-53129 & conv. & $80-85$ & $4200 \pm 80$ & Bulk & $4450-4956$ \\
\hline & Beta-53130 & conv. & $125-130$ & $5460 \pm 90$ & Bulk & $6001-6408$ \\
\hline & Beta-49708 & conv. & $155-160$ & $7040 \pm 120$ & Bulk & $7657-8155$ \\
\hline \multirow{5}{*}{$\begin{array}{l}\text { Portage Lake N. (P47-1) } \\
\text { collected in } 2010 \\
\text { Freeze core }\left(2 F_{-} F 2\right)\end{array}$} & UBA-17933 & AMS & $6.5-7$ & $772 \pm 24$ & Bulk & $673-729$ \\
\hline & UBA-17159 & AMS & $13.5-14$ & $4218 \pm 38$ & Bulk & $4626-4854$ \\
\hline & UBA-17160 & AMS & $41-41.5$ & $4885 \pm 37$ & Bulk & $\mathbf{5 5 8 4 - 5 7 1 0}$ \\
\hline & UBA-17161 & AMS & $63-63.5$ & $5333 \pm 35$ & Bulk & 5997-6264 \\
\hline & UBA-17162 & AMS & $86.5-87$ & $5878 \pm 34$ & Bulk & $6637-6783$ \\
\hline \multirow{4}{*}{$\begin{array}{l}\text { Waterloo Lake } \\
\text { collected in } 1987 ? \\
\text { Livingstone core }\end{array}$} & TO-3312 & AMS & $28-31$ & $4030 \pm 50$ & Bulk & $4413-4801$ \\
\hline & TO-3311 & AMS & $54-56$ & $4640 \pm 50$ & Bulk & $5090-5577$ \\
\hline & TO-3310 & AMS & $61-63.5$ & $5300 \pm 50$ & Bulk & 5939-6257 \\
\hline & TO-3313 & AMS & $75-77$ & $7640 \pm 100$ & Moss & $8206-8627$ \\
\hline \multirow{4}{*}{$\begin{array}{l}\text { Lake S41 } \\
\text { collected in } 2005 \\
\text { Livingstone core }\end{array}$} & UCI-25833 & AMS & $7-7.5$ & $375 \pm 15$ & Bulk & $331-499$ \\
\hline & UCI-25841 & AMS & $13.4-14$ & $1045 \pm 20$ & Bulk & 926-1042 \\
\hline & UCI-25836 & AMS & $23-23.5$ & $1985 \pm 15$ & Bulk & $1892-1987$ \\
\hline & UCI-25835 & AMS & $32.5-33$ & $2765 \pm 20$ & Bulk & 2789-2924 \\
\hline \multirow{5}{*}{$\begin{array}{l}\text { Queen's Lake } \\
\text { collected in } 1987 ? \\
\text { Livingstone core }\end{array}$} & WAT-1770 & conv. & $15-20$ & $3820 \pm 60$ & Bulk & $4010-4414$ \\
\hline & WAT-1771 & conv. & $45-50$ & $5600 \pm 60$ & Bulk & $6291-6493$ \\
\hline & WAT-1772 & conv. & $60-65$ & $6150 \pm 60$ & Bulk & $6888-7241$ \\
\hline & WAT-1773 & conv. & $100-105$ & $7150 \pm 70$ & Bulk & $7842-8159$ \\
\hline & TO-827 & AMS & 105 & $7470 \pm 80$ & Twig & $8060-8417$ \\
\hline \multirow{3}{*}{$\begin{array}{l}\text { McMaster Lake } \\
\text { collected in 1987? } \\
\text { Livingstone core }\end{array}$} & TO-766 & AMS & 10-12 & $3690 \pm 50$ & Bulk & $3888-4212$ \\
\hline & TO-158 & AMS & $20-22$ & $3680 \pm 60$ & Bulk & $3849-4220$ \\
\hline & ТO-767 & AMS & $30-32$ & $5120 \pm 60$ & Bulk & $5730-5990$ \\
\hline
\end{tabular}




\begin{tabular}{|c|c|c|c|c|c|c|}
\hline Lake information & Lab ID & Method & $\begin{array}{l}\text { Depth } \\
(\mathrm{cm})\end{array}$ & $\begin{array}{l}{ }^{14} \mathrm{C} \text { age }(\mathrm{BP}) \\
\pm 1 \sigma\end{array}$ & $\begin{array}{l}\text { Material } \\
\text { dated }\end{array}$ & $\begin{array}{l}\mathrm{Cal} \mathrm{BP} \pm \\
2 \sigma\end{array}$ \\
\hline & TO-156 & AMS & $40-42$ & $5360 \pm 60$ & Bulk & $5998-6279$ \\
\hline & TO-154 & AMS & $60-62$ & $6180 \pm 60$ & Bulk & $6943-7248$ \\
\hline UCLA Lake & TO-8840 & AMS & $20-21$ & $2370 \pm 50$ & Bulk & 2319-2698 \\
\hline \multirow[t]{6}{*}{ Livingstone core } & TO-8842 & AMS & $35-35.5$ & $4130 \pm 50$ & Bulk & $4527-4824$ \\
\hline & TO-8844 & AMS & $45-45.5$ & $5680 \pm 70$ & Bulk & $6317-6635$ \\
\hline & TO-8845 & AMS & $50-50.5$ & $6280 \pm 70$ & Bulk & $7002-7413$ \\
\hline & TO-8846 & AMS & $55.5-56$ & $7040 \pm 70$ & Bulk & $7707-7978$ \\
\hline & TO-8847 & AMS & $64.5-65$ & $7680 \pm 70$ & Bulk & $8382-8590$ \\
\hline & TO-8848 & AMS & $69.5-70$ & $7960 \pm 80$ & Bulk & 8605-9006 \\
\hline \multirow{2}{*}{$\begin{array}{l}\text { Carleton Lake (P49-1A) } \\
\text { collected in } 2010\end{array}$} & UBA-19464 & AMS & $9.5-10$ & $2794 \pm 34$ & Bulk & 2791-2970 \\
\hline & UBA-20002 & AMS & $15-15.5$ & $2778 \pm 26$ & Bulk & 2793-2950 \\
\hline \multirow[t]{4}{*}{ Freeze core $\left(2 F \_F 2\right)$} & UBA-20003 & AMS & $25-25.5$ & $2716 \pm 33$ & Bulk & $2757-2868$ \\
\hline & UBA-19465 & AMS & $32.5-33$ & $3124 \pm 41$ & Bulk & $3254-3443$ \\
\hline & UBA-19466 & AMS & $40.5-41$ & $3616 \pm 37$ & Bulk & $3835-4075$ \\
\hline & UBA-19467 & AMS & $66.5-67$ & $4927 \pm 38$ & Bulk & $5594-5728$ \\
\hline \multirow{7}{*}{$\begin{array}{l}\text { Carleton Lake }(\mathrm{P} 49-1 \mathrm{~B}) \\
\text { collected in } 2010 \\
\text { Freeze core }(1 \mathrm{~F})\end{array}$} & $U B A-18472$ & $A M S$ & $0-0.5$ & $1.0264 \pm 0.0035$ & Bulk & AD1955-1957 \\
\hline & UBA-17934 & AMS & $10-10.5$ & $1046 \pm 24$ & Bulk & $925-983$ \\
\hline & UBA-17347 & AMS & $19.5-20$ & $1925 \pm 25$ & Bulk & $1822-1926$ \\
\hline & UBA-17935 & AMS & $40-40.5$ & $2762 \pm 35$ & Bulk & 2780-2946 \\
\hline & UBA-17348 & AMS & $64.5-65$ & $3675 \pm 24$ & Bulk & $3926-4087$ \\
\hline & UBA-17936 & AMS & $80-80.5$ & $4635 \pm 32$ & Bulk & $5304-5465$ \\
\hline & UBA-17349 & AMS & $100-100.5$ & $5663 \pm 26$ & Bulk & $6399-6497$ \\
\hline \multirow{5}{*}{$\begin{array}{l}\text { Carleton Lake (R12-P49) } \\
\text { collected in } 2012 \\
\text { Freeze core }\left(2 F_{-} F 2\right)\end{array}$} & UBA-20612 & AMS & 10.0 & $702 \pm 39$ & Bulk & $560-699$ \\
\hline & UBA-20613 & AMS & 36.2 & $1337 \pm 31$ & Bulk & $1181-1305$ \\
\hline & UBA-20614 & AMS & 55.3 & $1302 \pm 46$ & Bulk & $1132-1304$ \\
\hline & UBA-20615 & AMS & 81.5 & $2132 \pm 31$ & Bulk & 2002-2299 \\
\hline & UBA-20616 & AMS & 117.8 & $2944 \pm 32$ & Bulk & 2989-3216 \\
\hline $\begin{array}{l}\text { Horseshoe Lake (P52-1) } \\
\text { collected in } 2010\end{array}$ & $\begin{array}{l}\text { UBA-17350 } \\
\text { UBA-17163 }\end{array}$ & $\begin{array}{l}\text { AMS } \\
\text { AMS }\end{array}$ & $\begin{array}{l}9-9.5 \\
18-18.5\end{array}$ & $\begin{array}{r}178 \pm 25 \\
1148 \pm 42\end{array}$ & $\begin{array}{l}\text { Bulk } \\
\text { Bulk }\end{array}$ & $\begin{array}{l}(-2)-291 \\
967-1172\end{array}$ \\
\hline \multirow[t]{8}{*}{ Freeze core $\left(2 F_{-} F 2\right)$} & UBA-17351 & AMS & $28-28.5$ & $2763 \pm 22$ & Bulk & $2785-2924$ \\
\hline & UBA-17352 & AMS & $38-38.5$ & $3343 \pm 23$ & Bulk & $3481-3639$ \\
\hline & UBA-19973 & AMS & 43.2 & $3776 \pm 36$ & Bulk & $3992-4281$ \\
\hline & UBA-17938 & AMS & $46-46.5$ & $4885 \pm 27$ & Bulk & $5589-5653$ \\
\hline & UBA-17165 & AMS & $55-55.5$ & $5916 \pm 58$ & Bulk & $6628-6897$ \\
\hline & UBA-17937 & AMS & $68-68.5$ & $6723 \pm 29$ & Bulk & $7516-7656$ \\
\hline & UBA-17166 & AMS & $80-80.5$ & $7488 \pm 40$ & Bulk & $8199-8383$ \\
\hline & UBA-17167 & AMS & $106-106.5$ & $8011 \pm 43$ & Bulk & 8718-9014 \\
\hline \multirow{4}{*}{$\begin{array}{l}\text { Lac de Gras (LDG) } \\
\text { collected in } 2010 \\
\text { Freeze core }\left(2 F \_F 2\right)\end{array}$} & UBA-17939 & AMS & $12-12.5$ & $1123 \pm 23$ & Bulk & $965-1067$ \\
\hline & UBA-17356 & AMS & 19-19.5 & $3299 \pm 38$ & Bulk & $3447-3631$ \\
\hline & UBA-17357 & AMS & $32-32.5$ & $1607 \pm 29$ & Bulk & $1412-1551$ \\
\hline & UBA-17358 & AMS & $46-46.5$ & $2144 \pm 35$ & Bulk & $2003-2305$ \\
\hline \multirow{4}{*}{$\begin{array}{l}\text { Lac de Gras (LDG_DM1) } \\
\text { collected in } 2012 \\
\text { Freeze core }\end{array}$} & D-AMS 001550 & AMS & $10-11$ & $784 \pm 23$ & Bulk & $677-732$ \\
\hline & D-AMS 001551 & AMS & $20-21$ & $1797 \pm 23$ & Bulk & $1629-1817$ \\
\hline & D-AMS 001552 & AMS & $30-31$ & $2636 \pm 25$ & Bulk & $2738-2781$ \\
\hline & D-AMS 001553 & AMS & $40-41$ & $3590 \pm 27$ & Bulk & $3836-3972$ \\
\hline Lac de Gras (LDG_DM3) & D-AMS 001554 & AMS & $10-11$ & $1719 \pm 23$ & Bulk & $1561-1696$ \\
\hline
\end{tabular}




\begin{tabular}{|c|c|c|c|c|c|c|}
\hline Lake information & Lab ID & Method & $\begin{array}{l}\text { Depth } \\
(\mathrm{cm})\end{array}$ & $\begin{array}{l}{ }^{14} \mathrm{C} \text { age (BP) } \\
\pm 1 \sigma\end{array}$ & $\begin{array}{l}\text { Material } \\
\text { dated }\end{array}$ & $\begin{array}{l}\text { Cal BP } \pm \\
2 \sigma\end{array}$ \\
\hline collected in 2012 & D-AMS 001555 & AMS & $20-21$ & $3459 \pm 26$ & Bulk & $3642-3828$ \\
\hline \multirow[t]{2}{*}{ Freeze core } & D-AMS 001556 & AMS & $30-31$ & $5509 \pm 28$ & Bulk & $6223-6396$ \\
\hline & D-AMS 001557 & AMS & $40-41$ & $7827 \pm 31$ & Bulk & $8543-8696$ \\
\hline Slipper Lake & ${ }^{210} \mathrm{~PB}$ Age & $\mathrm{n} / \mathrm{a}$ & 0 & $\mathrm{n} / \mathrm{a}$ & Bulk & $(-49)-(-45)$ \\
\hline collected in 1997 & ${ }^{210} \mathrm{~PB}$ Age & $\mathrm{n} / \mathrm{a}$ & 2 & $\mathrm{n} / \mathrm{a}$ & Bulk & $6-20$ \\
\hline \multirow[t]{3}{*}{ KB gravity and mini-Glew } & ${ }^{210} \mathrm{~PB}$ Age & $\mathrm{n} / \mathrm{a}$ & 3 & $\mathrm{n} / \mathrm{a}$ & Bulk & 34-94 \\
\hline & TO-9671 & AMS & $21.5-22.5$ & $3270 \pm 80$ & Bulk & 3359-3688 \\
\hline & TO-9672 & AMS & $43.5-44.5$ & $4760 \pm 70$ & Bulk & $5321-5603$ \\
\hline Lake TK-2 & Beta-167871 & AMS & $32-34$ & $2480 \pm 40$ & Bulk & $2365-2718$ \\
\hline collected in 1996 & Beta-167872 & AMS & $60-62$ & $3870 \pm 40$ & Bulk & $4157-4416$ \\
\hline \multirow[t]{5}{*}{ Livingstone core } & Beta-167873 & AMS & $96-98$ & $5670 \pm 40$ & Bulk & $6322-6558$ \\
\hline & TO-7871 & AMS & 132 & $7370 \pm 80$ & Twigs & $8020-8349$ \\
\hline & TO-7870 & AMS & 137 & $7190 \pm 80$ & Twigs & $7860-8178$ \\
\hline & TO-7869 & AMS & 142 & $7740 \pm 90$ & Twigs & $8375-8772$ \\
\hline & TO-7868 & AMS & 174 & $7780 \pm 70$ & Twigs & $8412-8761$ \\
\hline
\end{tabular}

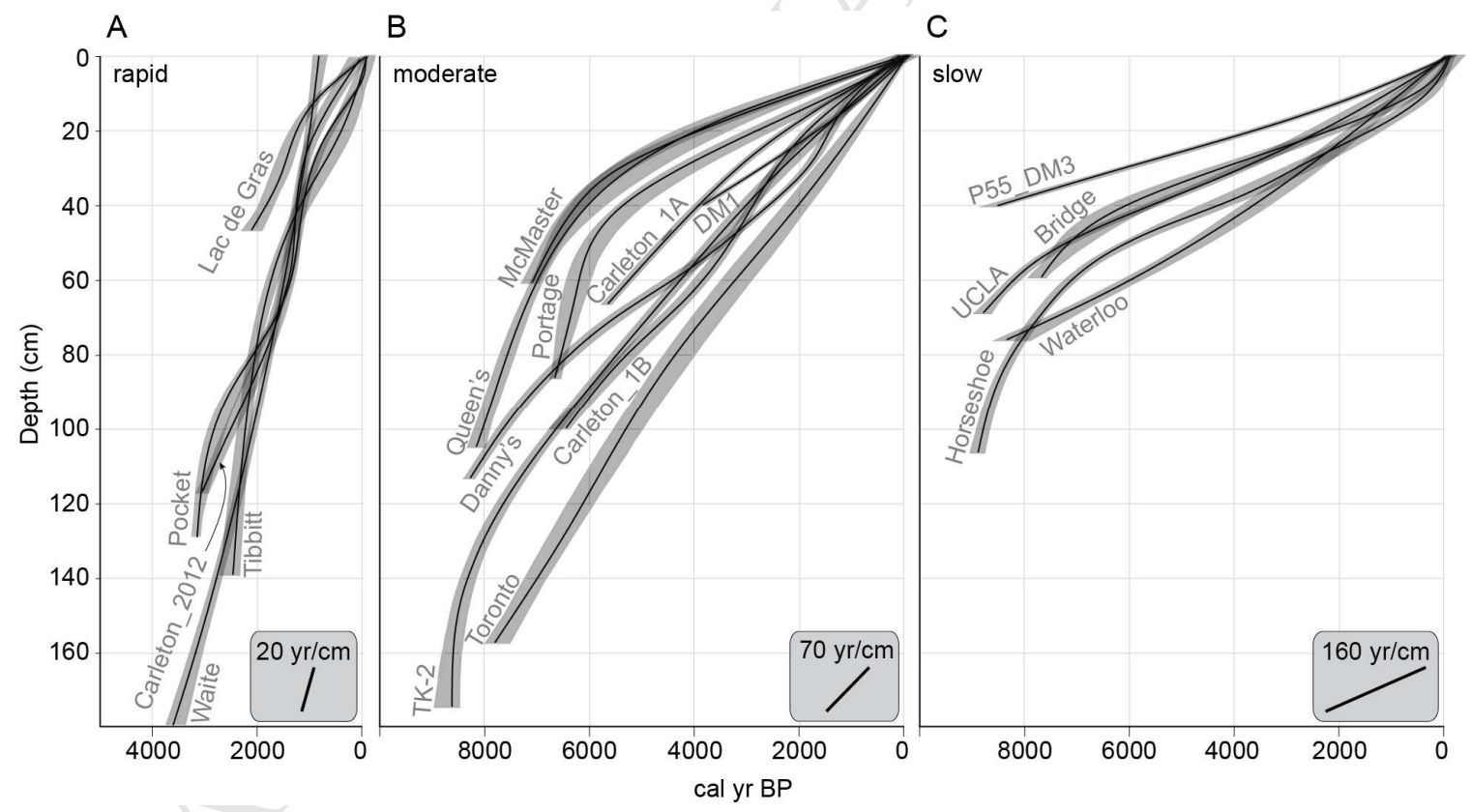

335 Figure 3. Age-depth models constructed using a smooth spline regression in Clam,

336 grouped into (a) rapid, (b) moderate, and (c) slowly accumulating sites. The 95\%

337 confidence interval is light grey. The scale for Waite Lake is to be used as a relative

338 measure only as the freeze corer over-penetrated the sediment-water interface. Two 
$3414.1 \quad$ Sites with rapid accumulation rates $(D T<50 \mathrm{yr} / \mathrm{cm})$

342 Rapid sediment accumulation rates are defined as having the DT for the majority of the

343 core of less than $50 \mathrm{yr} / \mathrm{cm}$. Five distinctive age depth models belonging to this category

344 were produced for cores from Lac de Gras, Pocket, Tibbitt, Waite and Carleton lakes.

345 Due to rapid sediment accumulation rates, these core records tend to span $\sim 3,500$ years at

346 most. The cores in this category yielded internally consistent age-depth models, with the

347 exception of one radiocarbon date that is a clear outlier in the Lac de Gras core (Table 2).

348 The average DT (rounded to the nearest $10=20 \mathrm{yr} / \mathrm{cm}$ ) is on par with lakes in the Great

349 Lakes region (Goring et al., 2012).

351 Deposition times in these lakes vary between c. 10 and $50 \mathrm{yr} / \mathrm{cm}$, with a mean of c. $20 \pm 10$

$352 \mathrm{yr} / \mathrm{cm}(1 \sigma)$ and a unimodal distribution, based on 107 DT measurements at 100-year

353 intervals (Fig. 4a). The accumulation pattern for Tibbitt Lake is different from the others

354 as it increases steadily from a DT of c. $5 \mathrm{yr} / \mathrm{cm}$ at c. $2,500 \mathrm{cal}$ BP to c. $50 \mathrm{yr} / \mathrm{cm}$ at the

355 top, but the very rapid deposition near the base overlaps the Hallstatt Plateau (c. 2,700-

356 2,300 cal BP; Blockley et al., 2007), which is a flat section in the IntCal09 calibration

357 curve and therefore may be an artifact of calibration. 


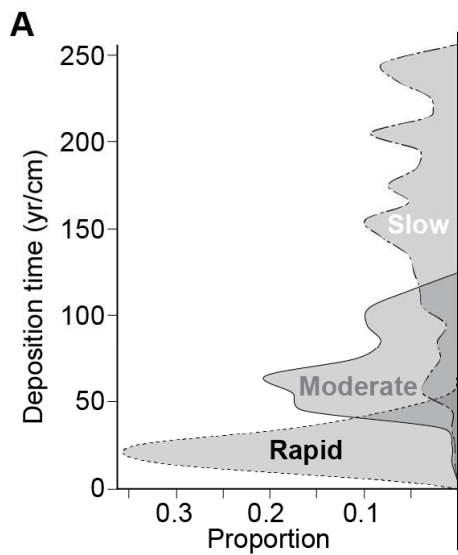

B

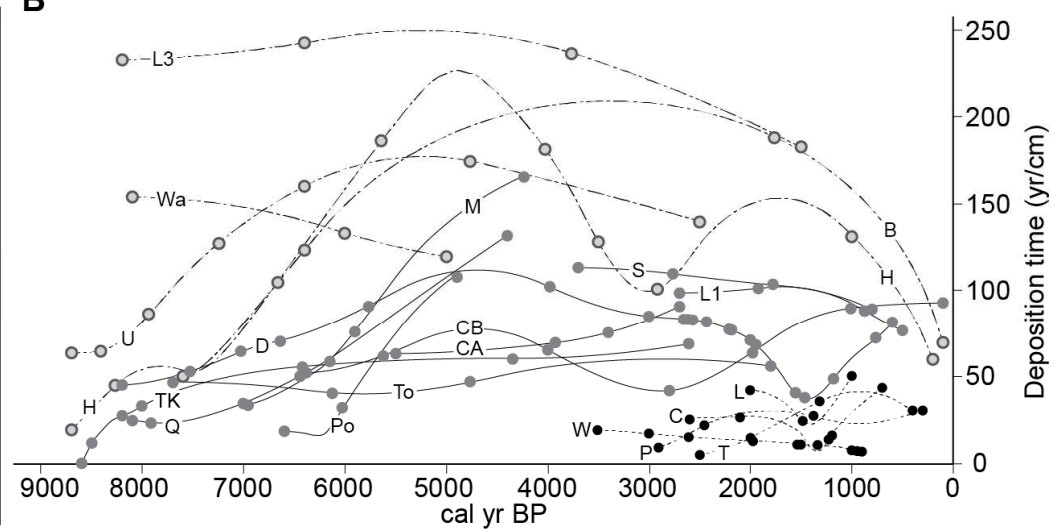

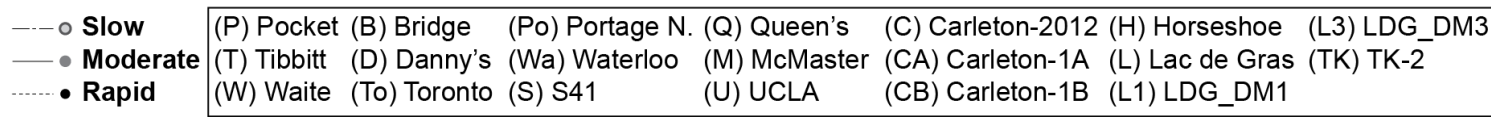

A

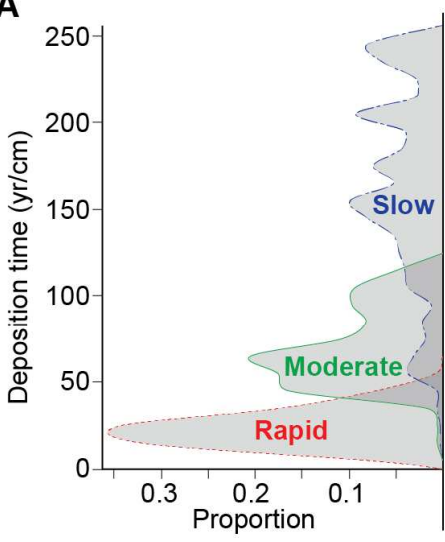

B

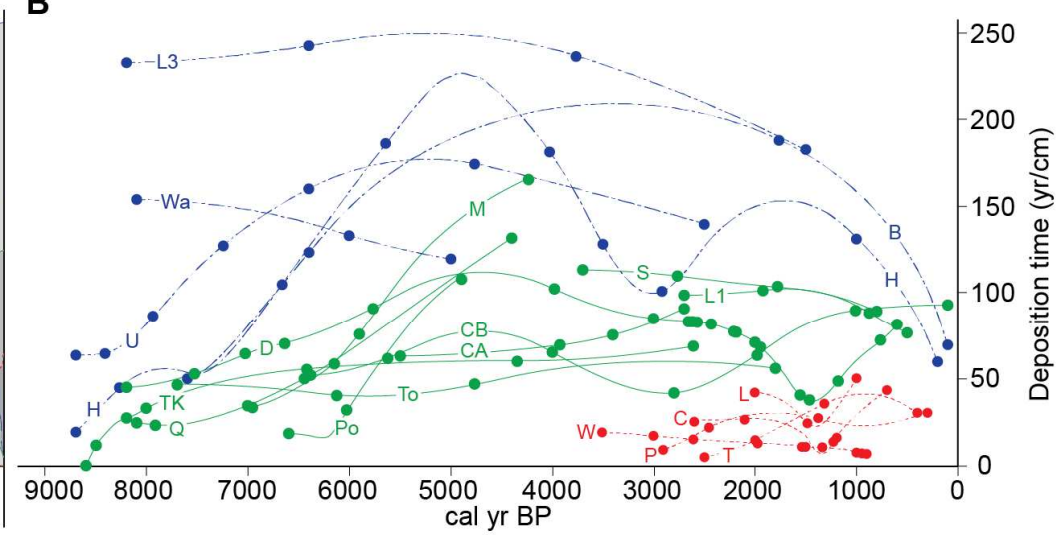

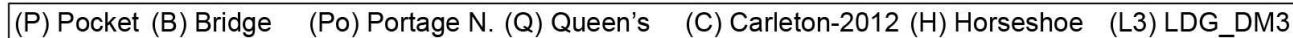
(T) Tibbitt (D) Danny's (Wa) Waterloo (M) McMaster (CA) Carleton-1A (L) Lac de Gras (TK) TK-2

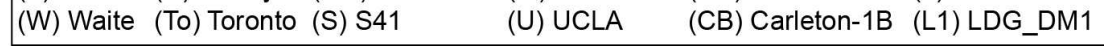

360 Figure 4. (a) Histogram of DT from rapid, moderate, and slowly accumulating lake site

361 categories, sampled at 100-year intervals from the age-depth models constructed in clam.

362 (b) Accumulation rate profiles for each site showing fluctuation of DT over time and the

363 variability between lake sites. The dots correspond to radiocarbon dates. Two column

364 image. Colour version for web only. Black and white for print.

367 The distinguishing characteristics of sites within this category include fluctuations in 
368 sediment accumulation rate at relatively subtle amplitudes (DT around $50 \mathrm{yr} / \mathrm{cm}$ ) and

369 DTs that do not generally exceed $100 \mathrm{yr} / \mathrm{cm}$. The sites in this category are Danny's,

370 Toronto, S41, Carleton-1A, Carleton-1B, LDG_DM1, and TK-2. Three of the cores in

371 the moderate accumulation rate category are characterized by a sedimentary record that

372 extends just beyond 8,000 cal BP. The other four cores in this category have records that

373 extend back between c. 6,000 and c. 4,000 cal BP (Fig. 3).

374

375 The outlier analysis performed in OxCal identified five outliers in the Danny's Lake core,

376 which were omitted from the smooth spline age-depth model constructed with Clam.

377 Four of the five outliers were older than the model and the fifth was only slightly

378 younger. For Carleton-1A, the upper three radiocarbon dates, at 9.5, 15 and $25 \mathrm{~cm}$, all

379 overlapped within the age range of c. 2,900 to c. 2,700 cal BP. For this reason the

380 uppermost two dates were omitted from the age-depth model constructed in Clam. The

381 overlap may have been the result of sediment mixing. The core from Lake TK-2 has an

382 age reversal within the bottommost four dates. Because these dates were obtained from

383 twigs (allochthonous origin and lack of heartwood), the reversal is likely due to delayed

384 deposition of older organic material. Clam was able to accept the reversal as the date was

385 within error of the others.

387 The lakes in this category accumulated with DTs between 50 and $100 \mathrm{yr} / \mathrm{cm}$ with a mean

388 of c. $70 \pm 20 \mathrm{yr} / \mathrm{cm}(1 \sigma)$ based on 343 DT measurements at 100-year intervals (Fig. 4).

389 The histogram shown in figure 4a has a bimodal distribution with a primary mode around $39060 \mathrm{yr} / \mathrm{cm}$ and a secondary mode around $100 \mathrm{yr} / \mathrm{cm}$. Most of the lakes in this category 
391 exhibit fluctuations in accumulation rate over time.

392

$3934.3 \quad$ Sites with slow accumulation rates $(D T 100-250 \mathrm{yr} / \mathrm{cm})$

394 Accumulation rates fluctuate in age-depth models for lakes with moderate and slow rates, 395 producing some overlapping characteristics. Sites with overall slow accumulation rates

396 fluctuate with DT amplitudes up to $150 \mathrm{yr} / \mathrm{cm}$ that tend to exceed $100 \mathrm{yr} / \mathrm{cm}$. The sites in

397 the slow accumulation category are Bridge, Waterloo, UCLA, Horseshoe, and

398 LDG_DM3. All five sites in this category extend back to at least c. 8000 cal BP or

399 beyond. The age-models are internally consistent, with only one outlier identified from

400 the Waterloo Lake age-depth model, where the age is older than the model (Fig. 3).

402 The histogram of DTs (Fig. 4a) is multi-modal, reflecting high variability of sediment

403 accumulation rates for cores within this category. The main pattern occurs between about

4048,000 and 5,000 cal BP, where Bridge, UCLA, and Horseshoe lakes are all characterized

405 by a slowing of accumulation rate (increased DT). This rate change is coincident with

406 changes in sedimentation from minerogenic-rich at the base of the core to organic-rich

407 above (Macumber et al., 2012). For Bridge Lake, the accumulation rate slows steadily

408 from a DT of $\sim 50 \mathrm{yr} / \mathrm{cm}$ at $7,600 \mathrm{cal} \mathrm{BP}$ to c. $200 \mathrm{yr} / \mathrm{cm}$ at $4,000 \mathrm{cal} \mathrm{BP}$. This

409 accumulation rate change is linked to a distinct color change at $\sim 4,200$ cal BP, from light

410 grey below (Munsell code 5y 3/2) to brown (Munsell code 10yr 2/1) above (Macumber et

411 al., 2012). The DT is constant around $200 \mathrm{yr} / \mathrm{cm}$ until c. 2,500 cal BP and steadily

412 increases to c. $160 \mathrm{yr} / \mathrm{cm}$ by $100 \mathrm{cal} \mathrm{BP}$.

413

414 The accumulation rate profile for Horseshoe Lake displayed the highest variability of any 
415 studied profile. Modeled DT is high (c. $20 \mathrm{yr} / \mathrm{cm}$ ) between $8,700-7,500 \mathrm{cal}$ BP and then

416 decrease to c. $225 \mathrm{yr} / \mathrm{cm}$ by $5,000 \mathrm{cal} \mathrm{BP}$. The transition around 7,500 cal BP is

417 associated with a shift from minerogenic-rich sediment at the core bottom to organic-rich

418 sediment above. Stratigraphically above $\sim 7,500$ cal BP, the accumulation rate gradually

419 increases; DT reaching c. $100 \mathrm{yr} / \mathrm{cm}$ by 3,000 cal BP, then decreasing to $150 \mathrm{yr} / \mathrm{cm}$ by

$4202,000 \mathrm{cal} \mathrm{BP}$, and finally increases again to $60 \mathrm{yr} / \mathrm{cm}$ at the core top.

$4224.4 \quad$ Sites with poor chronological constraint

423 Some sites do not easily fit into the three recognized categories, either due to lack of

424 dating resolution (P39 and Slipper lakes) or because the accumulation profile is

425 characterized by a dramatic shift in accumulation rate (Portage North, Queens, and

426 McMaster; Fig. 4). P39, Portage North, and McMaster lakes all had one outlier -

427 identified on an ad hoc basis - that fell between 5,000 and 4,000 cal BP (Fig. 3). For

428 P39, the radiocarbon date at the top of the core was determined to be an outlier. Because

429 the core was collected in only $110 \mathrm{~cm}$ water depth, upper lake sediments may have been

430 disturbed due to freezing of ice to the sediment-water interface. No further research was

431 undertaken on this core and accumulation rates were not estimated. Slipper Lake lacked

432 sufficient chronological control (based on two ${ }^{14} \mathrm{C}$ dates and a ${ }^{210} \mathrm{~Pb}$ profile) and was also

433 omitted from calculations of accumulation rate.

\section{5. Bayesian age-depth modeling with Bacon}

436 The temporal and spatial variations identified above are used as prior information for

437 three Bayesian age-depth models to demonstrate the power and robustness of this 
438 approach. The age modeling procedure for Bacon is similar to that outlined in Blaauw

439 and Christen (2005), but more numerous and shorter sections are used to generate a more

440 flexible chronology (Blaauw and Christen, 2011, 2013). Radiocarbon age distributions

441 are modeled using the Student- $t$ distribution, which produces calibrated distributions with

442 longer tails than obtained using the Normal model (Christen and Pérez, 2009). Due to the

443 longer tails on radiocarbon dates and a prior assumption of unidirectional sediment

444 accumulation, in most cases excluding outliers is not necessary when using Bayesian age

445 modeling. The cores from Waite, Danny's and Horseshoe lakes all have at least ten non-

446 outlying radiocarbon dates and were deemed suitable for Bayesian modeling with Bacon.

448 As this is a demonstration of the practical application of Bacon (version 2.2; Blaauw and

449 Christen, 2011, 2013), text in italics denotes the actual code typed in R (statistical

450 computing and graphics software). Bacon version 2.2 uses the currently most recent

451 calibration curve, IntCal13 (Reimer et al., 2013), and has an added feature of plotting

452 accumulation rate data with the plot.accrate.depth() and plot.accrate.age() functions. In

453 Section 6.3 we show a practical example of the accumulation rate plotting function.

455 Memory or coherence in accumulation rates along the core is a parameter that is defined

456 based on the degree to which the accumulation rate at each interval depends on the

457 previous interval. For example, the memory for modeling accumulation in peat

458 sediments should be higher than for lacustrine sediments because accumulation of peat in

459 peat bogs is less dynamic over time than the accumulation of sediments in a lake. Here

460 we used the memory properties from the lake example in Blaauw and Christen (2011; 
mem.strength $=20$ and mem.mean=0.1).

462

463 The accumulation rates (acc.rate=) for Waite and Danny's lakes were based on the DT

464 estimates from Section 4 (20, and 70, respectively). The accumulation shape

465 (acc.shape=) for the Waite Lake cores was set to 2, as suggested by Blaauw and Christen

466 (2011). The accumulation shape controls how much influence the accumulation rate will

467 have on the model. The default value of 2 is fairly low, thus the model has a fair amount

468 of freedom to adapt rates to what the data suggest. For the Danny's lake age model, the

469 accumulation shape was increased to a value of 20 to avoid perturbations in the model

470 caused by known outliers. The step size for Waite Lake was set to $5 \mathrm{~cm}$, which is the

471 default for a lake (Blaauw and Christen, 2011). The Danny's lake age-depth model

472 required more flexibility due to the observed shifts in accumulation rate that are unlikely

473 to be the product of spurious radiocarbon ages (they are sustained changes coherent with

474 known climate events), so the step sizes was lowered to $2 \mathrm{~cm}$.

476 Horseshoe Lake required the addition of a hiatus (hiatus.depths $=45$, hiatus.mean $=10$ ) in

477 order to produce a realistic, stable model. Because the hiatus accounts for the slowest

478 accumulation rates for the age-depth model (>150 yr/cm between c. $6000-4000 \mathrm{cal} \mathrm{BP})$,

479 the portion of the model below the hiatus accumulates at moderate rate (acc.mean=70,

480 acc.shape $=2$ ) and the portion of the model above the hiatus rate (acc. mean=20,

481 acc.shape $=1$ ). The physical nature of this hiatus is explored in Section 6.2.

483 The resulting age-depth models are shown in Figure 5, along with plots that describe: (1) 
484 the stability of the model (log objective vs. iteration); (2) the prior (entered by the user)

485 and posterior (resulting) accumulation rate, and; (3) the prior and posterior memory

486 properties. The Bayesian model from Waite Lake shows stable accumulation rates over

487 time, most likely because this core covers the latest Holocene, during which time climate

488 was relatively consistent (Karst-Riddoch et al. 2005; Rühland \& Smol 2005; Miller et al.

489 2010). Danny's Lake also yielded a stable model, with the consideration that the weight

490 on accumulation rate was set very high. The Horseshoe Lake model ran fairly stable,

491 with a minor perturbation.

492

493 The prior and posterior probability diagrams for accumulation rate were fairly similar for

494 Waite and Danny's lakes, and for Horseshoe Lake, the posterior distribution for

495 accumulation rate is a combination of the two assigned rates. Waite and Danny's lakes

496 models both showed memory of around 0.25 , which is higher than was assigned $(0.1)$.

497 The Horseshoe Lakes model had far less memory than assigned, but this is because

498 memory falls to 0 across a hiatus. 

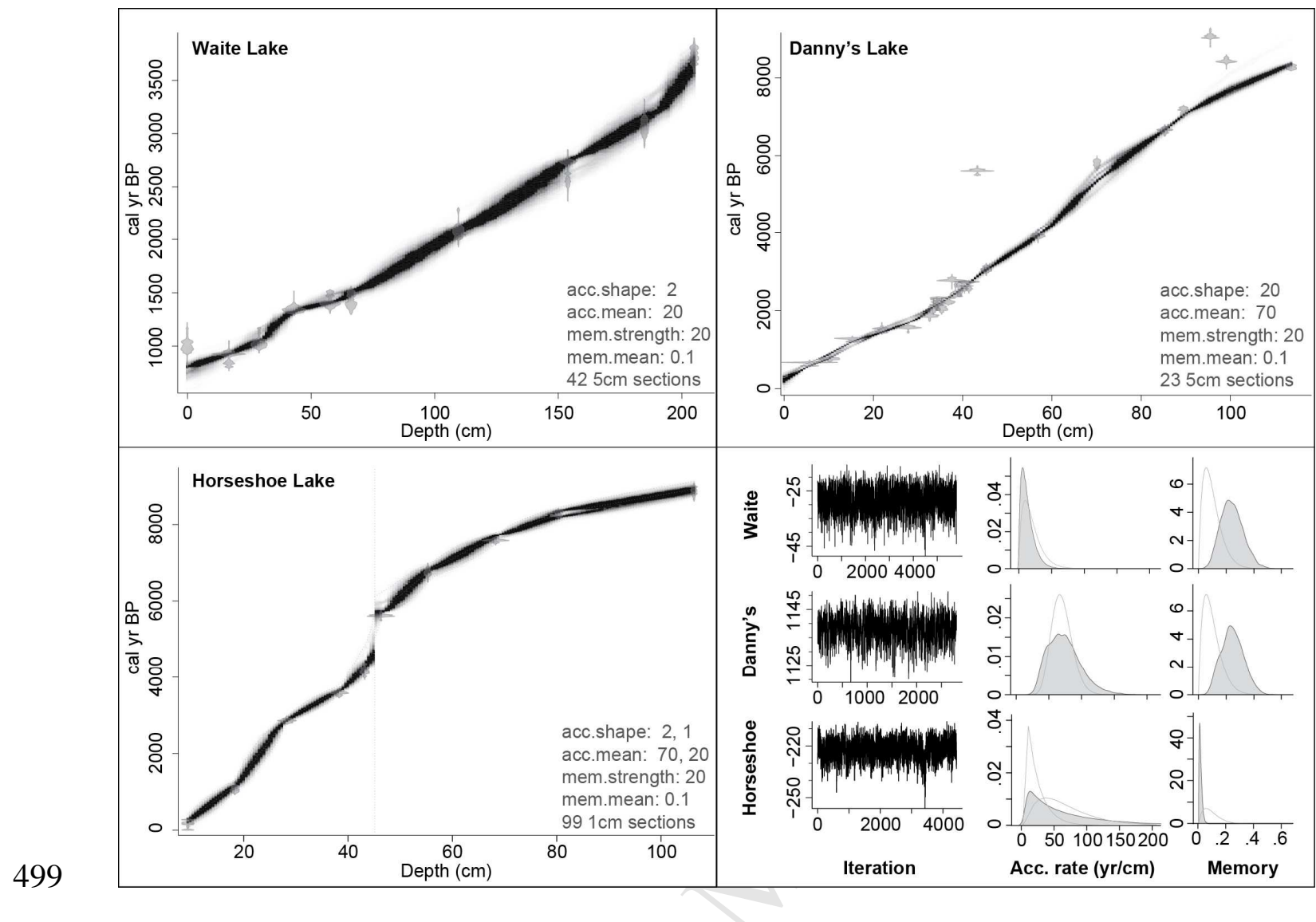

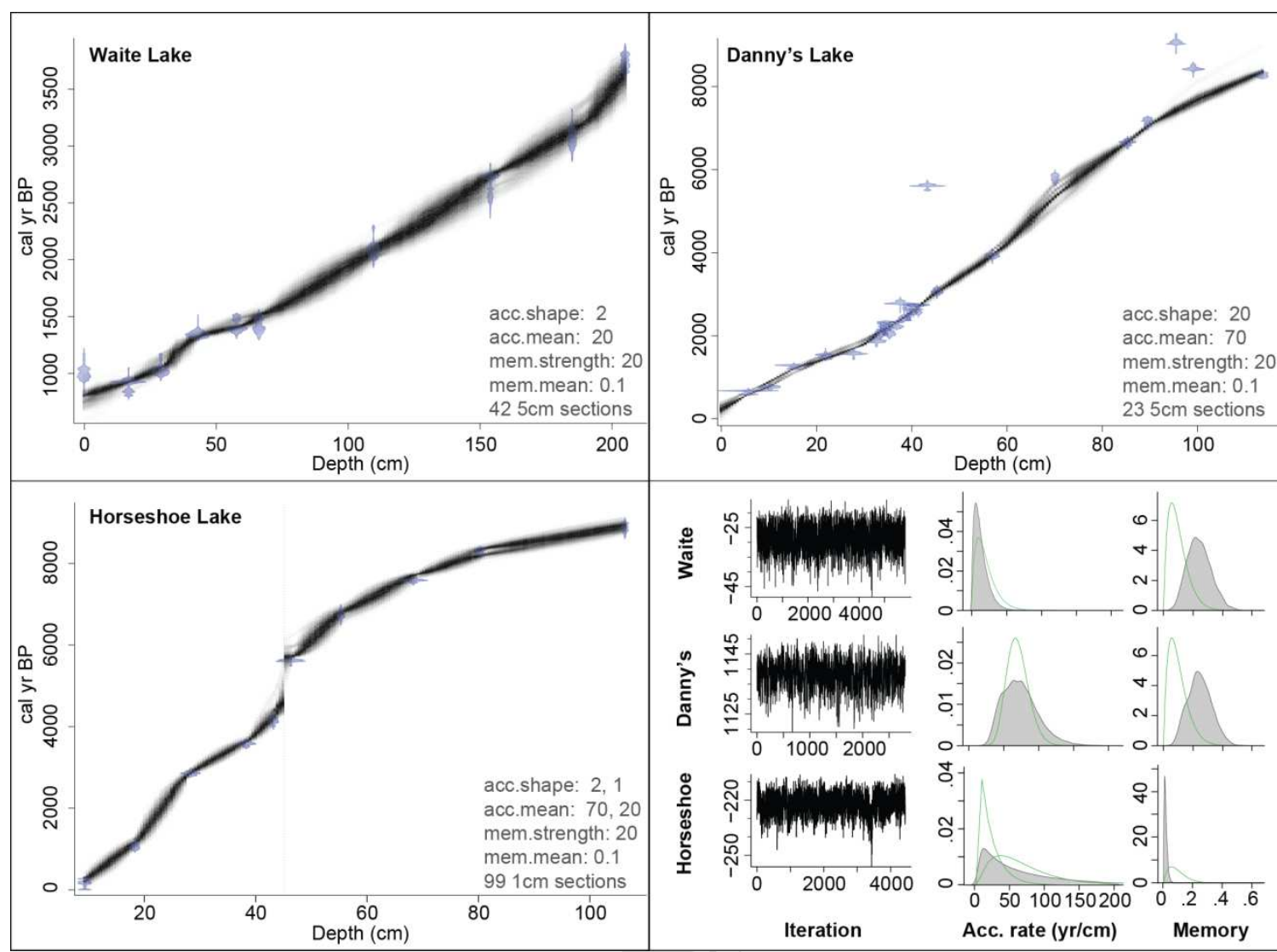

Figure 5. Bayesian age-depth models constructed with the age-depth modeling software

503 Bacon for Waite, Danny's, and Horseshoe lake cores. The grayscale on the model

504 represents the likelihood, where the darker the grey, the more likely the model is of

505 running through that section. The vertical, dashed line on the Horseshoe Lake model

506 denotes a hiatus. The bottom right panel shows three plots for each model: (left) stability

507 of the model; (middle) prior (line) and posterior (filled) distributions of accumulation

508 mean; and (right) prior (line) and posterior (filled) distributions of memory properties.

509 Double column image. Colour version for web only. Black and white for print.

\section{6. Discussion}

$512 \quad 6.1 \quad$ Spatial variability in accumulation rates 
513 The three southernmost boreal forest lakes (Pocket, Tibbitt, and Waite) have the highest

514 accumulation rates, suggesting that the accumulation rate may be can be related to in-lake

515 productivity and in-wash of organic detritus. Sediment accumulation rates at Bridge and

516 Danny's lakes are slower than the more productive boreal lakes; Pocket, Tibbitt, and

517 Waite lakes. The last c. 3,000 years of accumulation at Danny's lake mirrors the pattern

518 of rapidly accumulating sites, but is slower by about a DT of $10-20 \mathrm{yr} / \mathrm{cm}$. This suggests

519 that Danny's lake responded similarly to climate as the southernmost lakes, but may

520 either be slightly less productive due to colder temperatures at its location closer to the

521 polar front, or, judging by the bathymetry (Fig. 6), the coring site itself may receive less

522 sediment than the main basin of the lake, where sediment accumulation is most

523 commonly the greatest (c.f. Lehman, 1975). The accumulation rate at Bridge Lake is

524 extremely slow for the location south of the treeline and again we look at the bathymetry

525 for an explanation (Fig. 6). The coring location for Bridge Lake is nestled into a steep

526 slope, proximal to a deeper sub-basin with a much thicker sediment package. The slope

527 limits the amount of sediment that can accumulate at this site, and similarly to Danny's

528 Lake, much of the material is likely to have drifted toward the deeper basin.

530 Two of the most rapidly accumulating lakes are located in the tundra (Carleton-2012 and

531 Lac de Gras). Examination of the bathymetry profiles reveals certain basin features that

532 could explain the rapid accumulation rates (Fig. 6). Carleton Lake has a shallow shelf

533 over $500 \mathrm{~m}$ long that has a maximum depth of two meters, a slope covering less than 100

$534 \mathrm{~m}$, and a main basin that is about $500 \mathrm{~m}$ long at a depth of about $4 \mathrm{~m}$ (Fig. 6). The

535 Carleton-2012 freeze core was collected from a site closer to the slope and shelf than the 
536 Carleton-1A and Carleton-1B freeze cores. The shelf, which is situated in two meters

537 water depth, may be susceptible to re-suspension of fine detritus due to surface waves

538 touching bottom generated during windy or stormy conditions. The re-suspended

539 sediments would be transported down into the basin, with the majority being deposited

540 closer to the slope terminus. A similar trend has been noted at two Lakes in Estonia

541 whereby sediments deposited nearshore are thought to have eroded during a regressive

542 period and redeposited elsewhere (Punning et al., 2007a, 2007b; Terasmaa, 2011).

543 Looking at the bathymetry for Lac de Gras, it would be expected that since the coring site

544 is steep, sediment would by-pass and be deposited in the deeper part of the lake. It is

545 unclear, however, if there is a sub-basin at the coring site due to the low resolution of the

546 available bathymetry (Fig. 6). The coring site was characterized by turbid water, steep

547 surrounding landscape, and high minerogenic content of the core sediments (Macumber

548 et al. 2012). Therefore, the rapid accumulation rate at this site is likely due to in-wash of

549 material from the lake catchment. The other two cores from Lac de Gras (DM1 and

550 DM3) are in a completely different sub-basin of the lake. These cores exhibit moderate

551 to very slow accumulation rates, as would be expected on the tundra.

553 The Horseshoe lake core shows the highest variability in sedimentation rate of all the

554 lakes. The core was extracted from a steep-sided sub-basin of the main lake (Fig. 6).

555 The bathymetric profile is at a lower resolution than Bridge and Danny's lakes so it is not

556 possible to determine exactly how the sediments drape over the bedrock. What is

557 recognizable is that the sub-basin is only connected to the main basin by a shallow $(0.5 \mathrm{~m}$

558 deep) passage. The sub-basin therefore would receive little direct sediment input from 
560

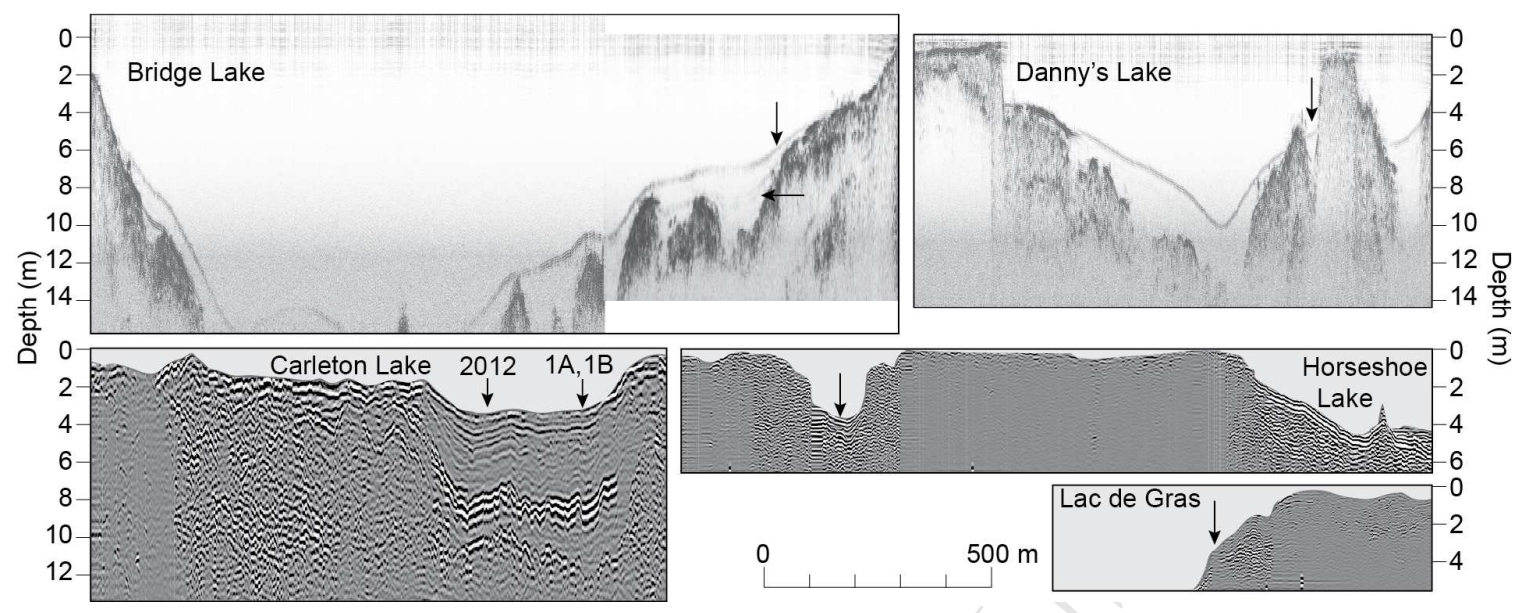

562 Figure 6. Bathymetry profiles from six lakes with arrows showing coring sites. The

563 horizontal arrow at Bridge Lake is pointing to a weak second reflector that is likely a

564 result of a change in sediment deposition from clay to gyttja, as observed in the core.

565 The coring site for Horseshoe Lake is in a sub-basin that is hydrologically connected to

566 the main basin through a meandering path as is shown in figure 3. Double column

567 image.

$569 \quad 6.2 \quad$ Temporal variability in accumulation rates

570 It is clear that the lakes in this region respond similarly during certain time periods (Fig.

5714 4). It is also noteworthy that the density of radiocarbon dates has an influence on the

572 observed shifts in accumulation rate. For example, Danny's Lake and Horseshoe Lake

573 are well-dated cores (25 and 10 radiocarbon dates, respectively) and the accumulation

574 profiles are much more dynamic than most of the others. This is an important point

575 because it emphasizes that the first means of improving an age-depth model should

576 always be to add more radiocarbon dates. However, because radiocarbon dates are 
577 expensive, it can be helpful to have an idea of when major shifts in accumulation rate for

578 a region are to be expected. That way, a more targeted approach can be employed when

579 refining an age-depth model using additional chronological control. Moreover, having an

580 idea of how the accumulation rate may shift over time for an age-depth model can assist

581 with identification of outliers as shown in section 3.3. Prior to a radiocarbon analysis,

582 major shifts in accumulation rate can be determined either visually (changes in sediment

583 composition) or by relatively inexpensive methods such as loss on ignition, magnetic

584 susceptibility, or palynology.

585

586 Seven of the ten cores that extend past about 7,000 cal BP show rapid accumulation rates

587 (DT $\sim 50 \mathrm{yr} / \mathrm{cm}$ ) at the base of their record and for nearly all these sites this is an above

588 average accumulation rate (Fig. 4). This rapid accumulation rate then steadily decreases

589 until c. 5,000 cal BP when most lakes with well-constrained age-depth models display the

590 slowest accumulation rates. At all seven sites, this occurs just after a transition from

591 minerogenic-rich sediment at the bottom to organic-rich sediment at the top (Fig. 7).

592 This is a common phenomenon in paraglacial environments when sediment availability

593 following glaciation is relatively high as long due to the presence of unstable drift

594 material in fluvial pathways (e.g. Church and Ryder, 1972; Ballantyne, 2002). Sediment

595 availability decreases as it is deposited, but also erosion rates are tempered as vegetation

596 is established (Huang et al., 2004). Results from an exponential exhaustion model by

597 Ballantyne (2002) support a decreasing accumulation rate over time as unstable sediment

598 is deposited. Briner et al. (2010) attribute the transition from minerogenic-rich to

599 organic-rich sediments to be indicative of the catchment for a proglacial lake getting cut 
600 off from a nearby glacier. While most cores show a gradual colour change toward the

601 basal sediments, the bottom $1 \mathrm{~cm}$ of Bridge Lake is composed of light grey clay that was

602 likely deposited in just such a proglacial setting. We also see evidence for this shift in

603 sediment type at Bridge Lake when looking at the bathymetry profile (Fig. 6), which

604 shows a weak, second reflector near the bottom of the core site. Around the transition

605 from minerogenic-rich sediments to organic-rich sediments, most lakes are characterized

606 by slowest accumulation rates, coeval with a period of treeline advance in the region

607 (Kaufman et al., 2004 and references therein). Similar relationships were noted for a lake

608 in the Cathedral Mountains of British Columbia (Evans and Slaymaker, 2004) and in a

609 crater lake in equatorial East Africa (Blaauw et al. 2011), whereby vegetation cover is

610 thought to slow terrestrial erosion and allochthonous sediment supply to lakes due to

611 physical stabilization of surficial materials. Following treeline advance, the accumulation

612 rates in cores with the highest dating resolution (Danny's, Carleton-1B, and Horseshoe

613 lakes) begin to increase again during late Holocene Cooling.

615 The accumulation rates for the cores from Lac de Gras, Carleton-2012 Lake, and Danny's

616 Lake increase sharply between $1,500 \mathrm{cal} \mathrm{BP}$ and $1,300 \mathrm{cal} \mathrm{BP}$, creating a small dip

617 toward increased accumulation rates (Fig. 4, 7). Anderson et al. (2012) also found an

618 increase in mineral accumulation rates at inland and coastal sites from c. 1,200 to 1,000

619 cal BP on southwest Greenland. They attribute this shift to regional cooling, increased

620 aridity, and increased delivery of allochthonous material to the lake. At Carleton Lake, a

621 cooling event between c, 1,690 and c. 940 cal BP is inferred based on chironomid proxy

622 data (Upiter et al., 2014) and is temporally correlative with the timing of First Millennial 
623 Cooling, a period of cool climatic conditions in the Northern Hemisphere and

624 documented in records from British Columbia (Reyes et al., 2006), Alaska (Hu et al.,

625 2001; Reyes et al., 2006; Clegg et al., 2010), and the Canadian Arctic Archipelago

626 (Thomas et al., 2011). Increased accumulation rates between c. 1,500 and c. 1,300 cal BP

627 may therefore correspond to cooling in the central NWT that would have resulted in a

628 brief period of reduced vegetation and consequently, increased erosion.

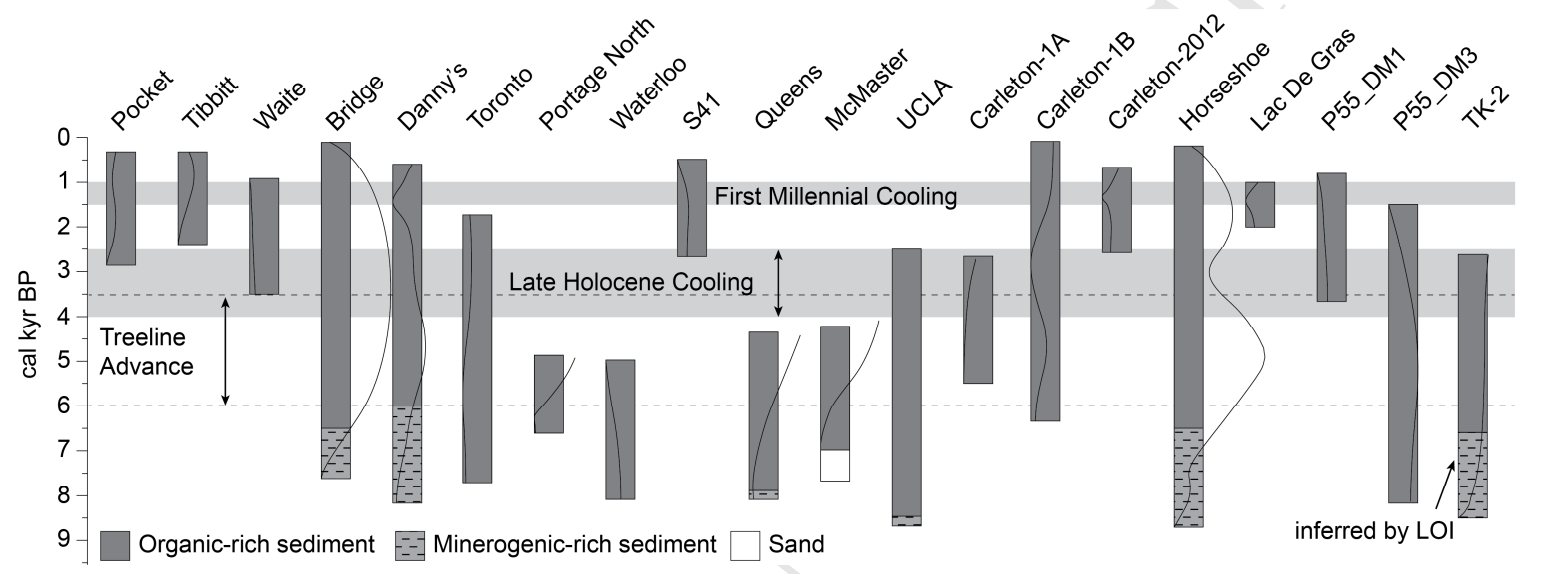

630 Figure 7. Stratigraphic core logs plotted against cal BP. The top of each core is defined

631 by the uppermost non-outlying radiocarbon date. Curved lines are accumulation profiles

632 from Fig. $4 \mathrm{~b}$ and are to be interpreted left to right is faster to slower. Time ranges for the

633 treeline advance and Late Holocene Cooling follow Kaufman et al. (2004), and First

634 Millennial Cooling follows Reyes et al. (2006), Hu et al. (2001), Clegg et al. (2010), and

635 Thomas et al. (2011). Double column image.

$637 \quad 6.3 \quad$ Accumulation rate (DT) prior

638 In Section 6.1 and 6.2, accumulation rates are discussed in terms of the natural

639 environment, which is a critical first step in any modeling study. In this section, we

640 switch gears to discuss the practical application of accumulation rates as prior 
641 information for age-depth modeling with Bayesian statistics.

642

643 The default DT prior for Bacon version 2.2 is $20 \mathrm{yr} / \mathrm{cm}$ based on the estimate from the

644 great lakes region by Goring et al. (2012). Bacon version 2.2 is programmed to suggest

645 an alternative DT based on round values (e.g. 10, 50, $100 \mathrm{yr} / \mathrm{cm}$ ) if the default of 20

$646 \mathrm{yr} / \mathrm{cm}$ is inappropriate for the core. As was shown for Waite Lake, $20 \mathrm{yr} / \mathrm{cm}$ is an

647 appropriate estimate for most lakes found in the boreal forest zone, but lakes north of the

648 treeline accumulated at much slower rates. Here we use estimates from a summary of

649 accumulation rate data for the region to construct the age-depth models in section 5. The

650 most striking feature of these age-depth models is how variable the accumulation rate

651 appears to be. Figure 8 (constructed using the plot.acc.rate() function in Bacon 2.2)

652 shows a more detailed version of accumulation rate patterns for the three cores from

653 Section 5. Waite Lake only covers the past c. 3,500 years so variability is minimal, but

654 both the longer Danny's and Horseshoe Lake records display highly variable

655 accumulation rates (as discussed in Section 6.2). The estimates for accumulation rate

656 entered a priori into the model therefore act as a guide for the age-depth model, but do

657 not control the model entirely.

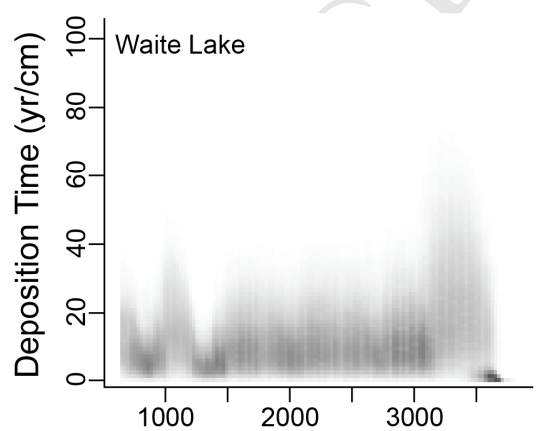

658

659 Figure 8. Accumulation profiles plotted with Bacon v2.2. The darker the grey, the 
660 greater the certainty. Double column image.

661

662 When an age-depth model is well dated, the dates themselves should guide the

663 accumulation rate. In sections of the core with low dating resolution or age reversals, the

664 Bayesian model can aid by incorporating prior information (Christen, 1994; Buck et al.,

665 1996; Buck and Millard, 2004; Blaauw and Heegaard, 2012). Here we compare the

666 Bayesian models to the Clam models in order to evaluate the effect of incorporating prior

667 information. Because the Clam models were initially constructed with IntCal09, we

668 reconstructed the models with IntCal13 order to ensure consistency (Supplementary Fig.

669 1). Moreover, a hiatus was added at $45 \mathrm{~cm}$ to the Horseshoe Lake model constructed

670 with Clam. Differences between the maximum probability age of the Bayesian model

671 and non-Bayesian model for Waite Lake, Danny's Lake, and Horseshoe Lake are

672 presented in Figure 9.

673

674 Waite Lake has the simplest chronology, with only one distinguishable shift in

675 accumulation rate just before c. 1,500 cal BP. The difference between the Bayesian and

676 non-Bayesian models is 90 years at the most, which is minimal. For Danny's Lake, the

677 difference between the two models is also fairly minimal (175 years at the most), which

678 happens near the bottom of the model where the greatest uncertainty lies.

680 The difference between Bayesian and non-Bayesian age depth models for the Horseshoe

681 Lake record does not tend to exceed 200 years, except in the region of the hiatus between

682 c. 6,000 and c. $4,000 \mathrm{cal} \mathrm{BP}(45 \mathrm{~cm})$, where the difference is 468 years. This is to be 
683 expected as the hiatus is handled slightly differently between the two programs and it

684 causes a major disturbance in the model. $\mathrm{C} / \mathrm{N}$ ratios from Horseshoe Lake suggest that

685 the sub-basin of Horseshoe Lake has undergone fluctuations in water depth (Griffith,

686 2013). Therefore, it is possible that there is a hiatus in deposition between c. 6,000 and c.

6874,000 cal BP. A hiatus would also explain the anomalously slow accumulation rates

688 around this period as shown in figure 4.

689

690 Although not shown in Figure 9, the age-depth models constructed with Bacon have

691 wider and more realistic calculated error ranges than for the smooth spline models

692 constructed with Clam.

693

694

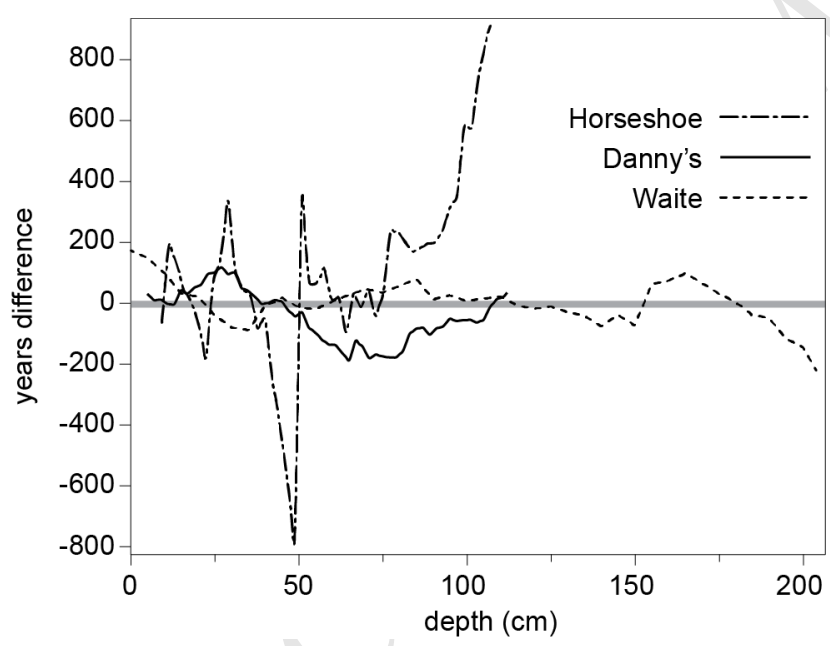




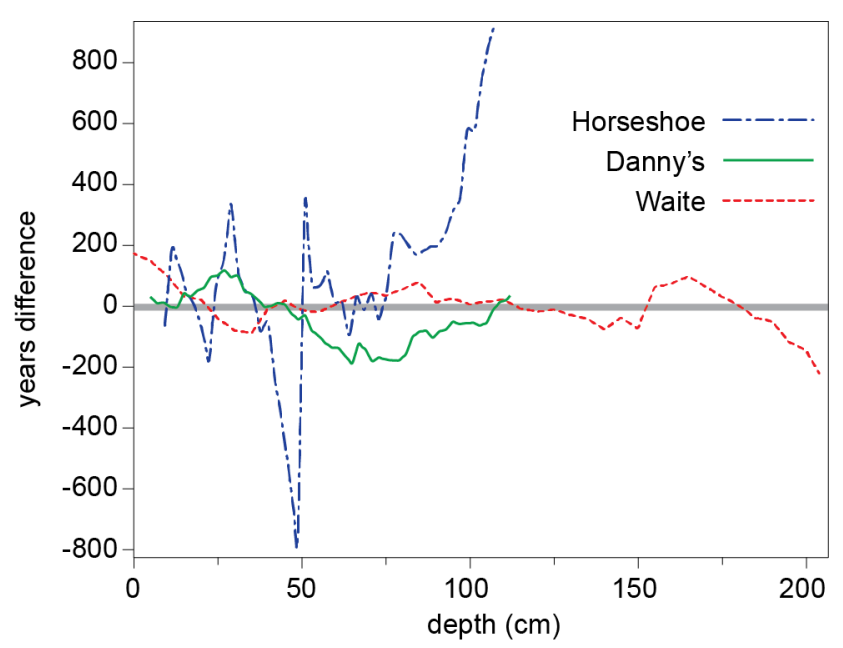

696 Figure 9. Plot showing the difference (in years) versus depth between the models

697 constructed in Clam and Bacon for the Horseshoe, Danny's and Waite Lake cores.

698 Single column image. Color for web version only.

$700 \quad 7 . \quad$ Conclusions

701 High resolution sampling and detailed age dating of subarctic lake cores from the

702 Northwest Territories have provided new information about the spatial and temporal

703 variability in lake accumulation rates in this cold, high latitude region. Based on a

704 dataset comprised of 105 radiocarbon dates (64 new and 41 previously published) from

70522 sites distributed amongst 18 lakes, we make the following conclusions:

706 (1) "Rapid" accumulation rates (DT 20 yr/m) tend to occur in lakes with high

707 productivity (boreal forest zone) or high sediment availability. Sites north of the treeline

708 are characterized by moderate (DT $\sim 70 \mathrm{yr} / \mathrm{cm}$ ) to slow (DT $>100 \mathrm{yr} / \mathrm{cm}$ ) accumulation

709 rates with high spatial variability.

710 (2) Temporal shifts in accumulation rates coincide with centennial to millennial-scale

711 climate change and the waxing and waning of vegetation cover, which is an important

712 mechanism controlling erosion of material into lakes. Accumulation rates prior to about 
7137,000 cal BP were rapid, reflecting recently deglaciated conditions characterized by high

714 sediment availability and low vegetation cover. As vegetation became better established

715 during the treeline advance, we observed a shift from minerogenic-rich to organic-rich

716 sediments and a decrease in accumulation rates between 7,000 and 4,000 cal BP. This

717 was followed by a cool period and increasing accumulation rates between $4,000 \mathrm{cal} \mathrm{BP}$

718 and 2,500 cal BP.

719 (3) Deposition time estimates from this research will be useful as a starting point for

720 building robust age-depth models using Bayesian statistics and state-of-the-art software

721 such as Bacon. Moreover, by elucidating the timing of regional shifts in accumulation

722 rate for the Canadian Subarctic, future radiocarbon dating sampling strategies will be

723 better informed about where to add additional radiocarbon dates to an age-depth model.

\section{Acknowledgements}

726 Funding for this collaborative research project was provided by a Natural Sciences and

727 Engineering Research Council of Canada (NSERC) Strategic Project Grant and

728 Discovery Grant to RTP and an Ontario Graduate Scholarship to CC. Direct and in-kind

729 funding was provided by the Northwest Territories Geoscience Office, Polar Continental

730 Shelf Project, the Department of Aboriginal Affairs and Northern Development Canada

731 (by, in part, a Cumulative Impacts and Monitoring Program award to JMG), the

732 Geological Survey of Canada, the Tibbitt to Contwoyto Winter Road Joint Venture (Erik

733 Madsen and the crew of the Dome, Lockhart, and Lac de Gras maintenance camps), EBA

734 Engineering Consultants Ltd., the North Slave Métis Alliance, IMG Golder, Inuvik, and

735 Golder Associates, Yellowknife. 


\section{References}

Abbott, M.B., Stafford, T.W., 1996. Radiocarbon geochemistry of modern and ancient Arctic lake systems, Baffin Island, Canada. Quaternary Research 45, 300-311. doi: 10.1006/qres.1996.0031

Anderson, N.J., Liversidge, A.C., McGowan, S., Jones, M.D., 2012. Lake and catchment response to Holocene environmental change: spatial variability along a climate gradient in southwest Greenland. Journal or Paleolimnology 48, 209-222. doi: 10.1007/s10933012-9616-3

Aravena, R., Warner, B.G., MacDonald, G.M., Hanf, K.I., 1992. Carbon isotope composition of lake sediments in relation to lake productivity and radiocarbon dating. Quaternary Research 37, 333-345. doi: 10.1016/0033-5894(92)90071-P

Ballantyne, C.K., 2002. Paraglacial geomorphology. Quaternary Science Reviews 21, 1935-2017. doi: 10.1016/S0277-3791(02)00005-7

Barnekow, L., Possnert, G., Sandgren, P., 1998. AMS ${ }^{14}$ C chronologies of Holocene lake sediments in the Abisko area, northern Sweden - a comparison between dated bulk sediment and macrofossil samples. GFF 120, 59-67. doi: 10.1080/11035899801201059 Blaauw, M., 2010. Methods and code for 'classical' age-modeling of radiocarbon sequences. Quaternary Geochronology 5, 512-518. doi: 10.1016/j.quageo.2010.01.002

Blaauw, M., 2010. Methods and code for 'classical' age-modeling of radiocarbon sequences. Quaternary Geochronology 5, 512-518. doi: 10.1016/j.quageo.2010.01.002

Blaauw, M., Christen, J.A., 2005. Radiocarbon peat chronologies and environmental change. Applied Statistics 54, 805-816. doi: 10.1111/j.1467-9876.2005.00516.x

Blaauw, M., Christen, J.A., 2011. Flexible paleoclimate age-depth models using an autoregressive gamma process. Bayesian Analysis 6, 457-474. doi: $10.1214 / \mathrm{ba} / 1339616472$

Blaauw, M., Christen, J.A., 2013. Bacon manual - v2.2. 11 pp. Last accessed February 28, 2014 at http://www.chrono.qub.ac.uk/blaauw/bacon.html.

Blaauw, M., van Geel, B., Kristen, I., Plessen, B., Lyaruu, A., Engstrom, D.R., van der Plicht, J., Verschuren, D., 2011. High-resolution 14C dating of a 25,000-year lakesediment record from equatorial East Afric. Quaternary Science Reviews 30, 3043-3059. doi: 10.1016/j.quascirev.2011.07.014

Blaauw, M., Heegaard, E., 2012. Estimation of age-depth relationships. In: Birks, H.J.B., Lotter, A.F., Juggins, S., Smol, P., (Eds.), Tracking Environmental Change Using Lake Sediments. Data Handling and Numerical Techniques. Vol. 5. Springer, Netherlands, pp. 379-413. doi: 10.1007/978-94-007-2745-8_12 
Blass, A., Bigler, C., Grosjean, M., Sturm, M., 2007. Decadal-scale autumn temperature reconstruction back to AD 1580 inferred from the varved sediments of Lake Silvaplana (southeastern Swiss Alps). Quaternary Research 68, 184-195. doi: 10.1016/j.yqres.2007.05.004

Bleeker, W., 2002. Archaean tectonics: a review, with illustrations from the Slave craton. Geological Society of London, Special Publications 199, 151-181. doi: 10.1144/GSL.SP.2002.199.01.09

Blockley, S.P.E., Blaauw, M., Bronk Ramsey, C., van der Plicht, J., 2007. Building and testing age models for radiocarbon dates in Lateglacial and Early Holocene sediments. Quaternary Science Reviews 26, 1915-1926. doi: 10.1016/j.quascirev.2007.06.007

Briner, J.P., Stewart, H.A.M., Young, N.E., Philipps, W., Losee, S., 2010. Using proglacial-threshold lakes to constrain fluctuations of the Jakobshavn Isbræ ice margin, western Greenland, during the Holocene. Quaternary Science Reviews 29, 3861-3874. doi: 10.1016/j.quascirev.2010.09.005

Bronk Ramsey, C., 2009a. Dealing with outliers and offsets in radiocarbon dating. Radiocarbon 51, 1023-1045.

Bronk Ramsey, C., 2009b. Bayesian analysis of radiocarbon dates. Radiocarbon 51, 337360.

Buck, C.E., Cavanagh, W.G., Litton C.D., 1996. Bayesian approach to interpreting archaeological date. Wiley, Chichester.

Buck, C.E., Millard, A.R. (Eds.), 2004. Tools for constructing chronologies: crossing disciplinary boundaries. Springer-Verlag, London. doi: 10.1007/978-1-4471-0231-1

Charman , D.J., Beilman, D.W., Blaauw, M., Booth, R.K., Brewer, S., Chambers, F.M., Christen, J.A., Gallego-Sala, A., Harrison, S.P., Hughes, P.D.M., Jackson, S.T., Korhola, A., Mauquoy, D., Mitchell, F.J.G., Prentice, I.C., van der Linden, M., De Vleeschouwer, F., Yu, Z.C., Alm, J., Bauer, I.E., Corish, Y.M.C., Garneau, M., Hohl, V., Huang, Y., Karofeld, E., Le Roux, G., Loisel, J., Moschen, R., Nichols, J.E., Nieminen, T.M., MacDonald, G.M., Phadtare, N.R., Rausch, N., Sillasoo, Ü, Swindles, G.T., Tuittila, E.S., Ukonmaanaho, L., Välliranta, M., van Bellen, S., van Geel, B., Vitt, D.H., Zhao, Y., 2013. Climate-related changes in peatland carbon accumulation during the last millennium. Biogeosciences 10, 929-944 www.biogeosciences.net/10/929/2013/

Christen, J.A., 1994. Bayesian interpretation of radiocarbon results. Ph.D. thesis, University of Nottingham.

Christen, J.A., Pérez E.S., 2009. A new robust statistical model for radiocarbon data. Radiocarbon 51, 1047-1059. 
872 Glew, J.R., Smol, J.P., Last, W.M., 2001. Sediment core collection and extrusion. In:

873 Last, W.M., Smol, J.P. (Eds.), Tracking environmental changes using lake sediments:

Church, M., Ryder, J.M., 1972. Paraglacial sedimentation: a consideration of fluvial processes conditioned by glaciation. Geological Society of America Bulletin 83, 30593072. doi: 10.1130/0016-7606(1972)83[3059:PSACOF]2.0.CO;2

Clayton, J.S., Ehrlich, W., Cann, D.B., Day, J.H., Marshall, I.B., 1977. Soils of Canada. Soil Inventory Research Branch, Canada, vol. II. Department of Agriculture, Ottawa. 239 pp.

Clegg, B.F., Clarke, G.H., Chipman, M.L., Chou, M., Walker, I.R., Tinner, W., Hu, F.S., 2010. Six millennia of summer temperature variation based on midge analysis of lake sediments from Alaska. Quaternary Science Reviews 29, 3308-3316. doi: 10.1016/j.quascirev.2010.08.001

Cockburn, J.M.H., Lamoureux, S.F., 2008. Inflow and lake controls on short-term mass accumulation and sedimentary particle size in a High Arctic Lake: implications for interpreting varved lacustrine sedimentary records. Journal of Paleolimnology 40, 923942. doi: 10.1007/s10933-008-9207-5

Crann, C., 2013. Spatial and temporal variability of lake accumulation rates in Subarctic Northwest Territories, Canada. MSc thesis, Carleton University.

Dyke, A.S., Prest, V.K., 1987. Late Wisconsinan and Holocene history of the Laurentide Ice Sheet. Géographie Physique et Quaternaire 41, 237-263. doi: 10.7202/032681ar

Dyke, A.S., Moore, A., Robertson, L., 2003. Deglaciation of North Americ. Geological Survey of Canada Open File, 1574. doi: 10.4095/214399

Evans, M., Slaymaker, O., 2004. Spatial and temporal variability of sediment delivery from alpine lake basins, Cathedral Provincial Park, southern British Columbia.

Geomorphology 61, 209-224. doi: 10.1016/j.geomorph.2003.12.007

Galloway, J.M., Macumber, A.L., Patterson, R.T., Falck, H., Hadlari, T., Madsen, E., 2010. Paleoclimatological assessment of the southern Northwest Territories and implicatons for the long-term viability of the Tibbitt to Contwoyto Winter Road, part 1: core collection. Northwest Territories Geoscience Office, NWT Open Report 2010-002, $21 \mathrm{p}$.

Geyh, M.A., Schotterer, U., Grosjean, M., 1998. Temporal changes of the 14 C reservoir effect in lakes. Radiocarbon 40, 921-931.

Glew, J.R., 1991. Miniature gravity corer for recovering short sediment cores. Journal of Paleolimnology 5, 285-287. doi: 10.1007/BF00200351 
874 Volume 1: Basin analysis, coring and chronological techniques. Dordrecht: Kluwer 875 Academic Publishers p 73-105.

Goring, S., Williams, J.W., Blois, J.L., Jackson, S.T., Paciorek, C.J., Booth, R.K., Marlon, J.R., Blaauw, M., Christen, J.A., 2012. Accumulation rates in the northeastern United States during the Holocene: establishing valid priors for Bayesian age models.

Quaternary Science Reviews 48, 54-60. doi: 10.1016/j.quascirev.2012.05.019

Grimm, E.C., Maher Jr., L.J., Nelson, D.M., 2009.The magnitude of error in conventional bulk-sediment radiocarbon dates from central North Americ. Quaternary Research 72, 301-308. doi: 10.1016/j.yqres.2009.05.006

Helmstaedt, H., 2009. Crust-mantle coupling revisited: The Archean Slave craton, NWT, Canada. Lithos 112S, 1055-1068. doi: 10.1016/j.lithos.2009.04.046

Hu, F.S., Ito, E., Brown, T.A., Curry, B.B., Engstrom, D.R., 2001. Pronounced climatic variations in Alaska during the last two millennia. Proceedings of the National Academy of Sciences 98, 10552-10556. doi: 10.1073/pnas.181333798

Hua, Q., Barbetti, M., 2004. Review of tropospheric bomb 14C data for carbon cycle modeling and age calibration purposes. Radiocarbon 46, 1273-1298.

Hua, Q., Barbetti, M., Rakowski, A.Z., 2013. Atmospheric radiocarbon for the period 1950-2010. Radiocarbon 55, doi:10.2458/azu_js_rc.v55i2.16177

898 Huang, C.C., MacDonald, G., Cwynar, L., 2004. Holocene landscape development and 899 climatic change in the low arctic, Northwest Territories, Canada. Palaeogeography, 900 Palaeoclimatology, Palaeoecology 205, 221-234. doi: 10.1016/j.palaeo.2003.12.009

901

902

903

904

905

906

907

Karst-Riddoch, T., Pisaric, M. \& Smol, J., 2005, Diatom responses to 20th century climate-related environmental changes in high-elevation mountain lakes of the northern Canadian Cordillera. Journal of Paleolimnology 33, 265-282.

Kaufman, D.S., Ager, T.A., Anderson, N.J., Anderson, P.M., Andrews, J.T., Bartlein, P.J., Brubaker, L.B., Coats, L.L., Cwynar, L.C., Duvall, M.L., Dyke, A.S., Edwards, M.E., Eisner, W.R., Gajewski, K., Geirsdóttir, A., Hu, F.S., Jennings, A.E., Kaplan, M.R., Kerwin, M.W., Lozhkin, A.V., MacDonald, G.M., Miller, G.H., Mock, C.J., Oswald, W.W., Otto-Bliesner, B.L., Porinchu, D.F., Rühland, K., Smol, J.P., Steig, E.J., Wolfe, B.B., 2004. Holocene thermal maximum in the western Arctic (0-180 W). Quaternary Science Reviews 23, 529-560. doi: 10.1016/j.quascirev.2003.09.007

Koff, T., Punninga, J.-M., Kangura, M., 2000. Impact of forest disturbance on the pollen influx in lake sediments during the last century. Review of Palaeobotany and Palynology 111, 19-29. doi: 10.1016/S0034-6667(00)00013-0 
918 Kulbe, T., Niederreiter Jr., R., 2003. Freeze coring of soft surface sediments at a water 919 depth of several hundred meters. Journal of Paleolimnology 29, 257-263. doi:

920 10.1023/A:1023209632092

921

922

923

924

925

926

927

928

929

930

931

932

933

934

935

936

937

938

939

940

941

942

Lehman, J., 1975. Reconstructing the rate of accumulation of lake sediment: the effect of sediment focusing. Quaternary Research 5, 541-550. doi: 10.1016/0033-5894(75)900150

Lerbekmo, J.F., 2008. The White River Ash: largest Holocene Plinian tephra. Canadian Journal of Earth Sciences 45, 693-700. doi: 10.1139/E08-023

Lotter, A.F., Renberg, I., Hansson, H., Sto $\square$ ckli, R., Sturm, M., 1997. A remote controlled freeze corer for sampling unconsolidated surface sediments. Aquatic Sciences 59, 295-303.

MacDonald, G.M., Edwards, T.W.D., Moser, K.A., Pienitz, R., Smol, J.P., 1993. Rapid response of treeline vegetation and lakes to past climate warming. Nature 361, 243-246. doi: $10.1038 / 361243 \mathrm{a} 0$

MacDonald, G.M., Porinchu, D.F., Rolland, N., Kremenetsky, K.V., Kaufman, D.S., 2009. Paleolimnological evidence of the response of the central Canadian treeline zone to radiative forcing and hemispheric patterns of temperature change over the past 2000 years. Journal of Paleolimnology 41, 129-141. doi: 10.1007/s10933-008-9250-2

Macumber, A.L., Patterson, R.T., Neville, L.A., Falck, H., 2011. A sledge microtome for high resolution subsampling of freeze cores. Journal of Paleolimnology 45, 307-310. doi: 10.1007/s10933-010-9487-4

Macumber, A.L., Neville, L.A., Galloway, J.M., Patterson, R.T., Falck, H., Swindles, G., Crann, C., Clark, I., Gammon, P., Madsen, E., 2012. Paleoclimatological assessment of the Northwest Territories and implications for the long-term viability of the Tibbitt to Contwoyto Winter Road, part II: March 2010 field season results. Northwest Territories Geoscience Office, NWT Open Report 2011-010, pp. 83.

Marlon, J., Bartlein, P.J., Whitlock, C., 2006. Fire-fuel-climate linkages in the northwestern USA during the Holocene. The Holocene 16, 1059-1071. doi: $10.1177 / 0959683606069396$

Miller, G., Brigham-Grette, J., Alley, R., Anderson, L., Bauch, H., Douglas, M., 958 Kaufman, D. S., MacDonald, G. M., Polyak, L., Robock, A., Serreze, M., Smol, J., 959 Spielhagen, R., White, J., Wolfe, A. \& Wolff, E., 2010. Temperature and precipitation 960 history of the Arctic. Quaternary Science Reviews 29, 1679-1715. 
Moser, K.A., MacDonald, G.M., 1990. Holocene vegetation change at treeline north of Yellowknife, Northwest Territories, Canada. Quaternary Research 34, 227-239. doi: 10.1016/0033-5894(90)90033-H

Oana, S., Deevey, E.S., 1960. Carbon 13 in lake waters and its possible bearing on paleolimnology. American Journal of Science 258, 253-272.

Padgham, W.A., Fyson, W.K., 1992. The slave province: a distinct Archean craton.

Canadian Journal of Earth Science 29, 2072-2086. doi: 10.1139/e92-165

Paul, C.A., Ru $\square$ hland, K.M., Smol, J.P., 2010. Diatom-inferred climatic and environmental changes over the last $~ 9000$ years from a low Arctic (Nunavut, Canada) tundra lake. Palaeogeography, Palaeoclimatology, Palaeoecology 291, 205-216.

Pientiz, R., Smol, J.P., MacDonald G.M., 1999. Paleolimnological reconstruction of Holocene climate trends from two boreal treeline lakes, Northwest Territories, Canada. Arctic, Antarctic, and Alpine Research 31, 82-93. doi: 10.2307/1552625

Pyne-O'Donnell, S.D.F., Hughes, P.D.M., Froese, D.G., Jensen, B.J.L., Kuehn, S.C., Mallon, G., Amesbury, M.J., Charman, D.J., Daley, T.J., Loader, N.J., Mauquoy, D., Street-Perrott, F.A., Woodman-Ralph, J., 2012. High-precision ultra-distal Holocene tephrochronology in North Americ. Quaternary Science Reviews 52, 6-11. doi: 10.1016/j.quascirev.2012.07.024

Punning, J.-M., Koff, T., Sakson, M., Kangur, M., 2007a. Holocene pattern of organic carbon accumulation in a small lake in Estonia. Polish Journal of Ecology 55, $5-14$.

Punning, J.-M., Boyle, J.F., Terasmaa, J., Vaasma, T., Mikomägi, A., 2007b. Changes in lake sediment structure and composition caused by human impact: repeated studies of Lake Martiska, Estonia. The Holocene, 17, 145-151. doi: 10.1177/0959683607073297 Rampton, V.N., 2000. Large-scale effects of subglacial meltwater flow in the southern Slave Province, Northwest Territories, Canada. Canadian Journal of Earth Science 37, 81-93. doi: 10.1139/e99-110

Reimer, P.J., Brown, T.J., Reimer, R.W., 2004. Discussion: reporting and calibration of post-bomb 14C data. Radiocarbon 46, 1299-1304.

Reimer, P.J., Baillie, M.G.L., Bard, E., Bayliss, A., Beck, J.W., Blackwell, P.G., Bronk Ramsey, C., Buck, C.E., Burr, G.S., Edwards, R.L., Friedrich, M., Grootes, P.M., Guilderson, T.P., Hajdas, I., Heaton, T.J., Hogg, A.G., Hughen, K.A., Kaiser, K.F., Kromer, B., McCormac, F.G., Manning, S.W., Reimer, R.W., Richards, D.A., Southon, J.R., Talamo, S., Turney, C.S.M., van der Plicht, J., Weyhenmeyer, C.E., 2009. IntCal09 and Marine09 radiocarbon age calibration curves, 0-50,000 years cal BP. Radiocarbon $51,1111-1150$.

1008 
1009

1010

1011

1012

1013

1014

1015

1016

1017

1018

1019

1020

1021

1022

1023

1024

1025

1026

1027

1028

1029

1030

1031

1032

1033

1034

1035

1036

1037

1038

1039

1040

1041

1042

1043

1044

1045

1046

1047

1048

1049

1050

1051

1052

1053

1054

Reimer, P.J., Bard, E., Bayliss, A., Beck, J.W., Blackwell, P.G., Bronk Ramsey, C., Buck, C.E., Cheng, H., Edwards, R.L., Friedrich, M., Grootes, P.M., Guilderson, T.P., Haflidason, H., Hajdas, I., Hatté, C., Heaton, T.J., Hoffmann, D.L., Hogg, A.G., Hughen, K.A., Kaiser, K.F., Kromer, B., Manning, S.W., Niu, M., Reimer, R.W., Richards, D.A., Scott, E.M., Southon, J.R., Staff, R.A., Turney, C.S.M., van der Plicht, J., 2013. IntCal13 and Marine13 Radiocarbon Age Calibration Curves 0-50,000 Years cal BP. Radiocarbon 55, 1869-1887. Doi: 10.2458/azu_js_rc.55.16947

Reyes, A.V., Wiles, G.C., Smith, D.J., Barclay, D.J., Allen, S., Jackson, S., Larocque, S., Laxton, S., Lewis, D., Calkin, P.E., Clague, J.J., 2006. Expansion of alpine glaciers in Pacific North America in the first millennium A.D. Geology 34, 57-60. doi: $10.1130 / G 21902.1$

Robinson, S.D., 2001. Extending the late Holocene White River Ash distribution, Northwestern Canada. Arctic 54, 157-161.

Rühland, K., Smol, J.P., 2005. Diatom shifts as evidence for recent Subarctic warming in a remote tundra lake, NWT, Canada. Palaeogeoprahy, Palaeoclimatology, Palaeoecology 226, 1-16. doi: 10.1016/j.palaeo.2005.05.001

Saulnier-Talbot, E., Pienitz, R., Stafford Jr., T.W., 2009. Establishing Holocene sediment core chronologies for northern Ungava lakes, Canada, using humic acids (AMS 14C) and 210Pb. Quaternary Geochronology 4, 278-287. doi: 10.1016/j.quageo.2009.02.018

Schiefer, E., 2006. Contemporary sedimentation rates and depositional structures in a montane lake basin, southern Coast Mountains, British Columbia, Canada. Earth Surface Processes and Landforms 31, 1311-1324. doi: 10.1002/esp.1332

Smith, D.G., 1994. Glacial Lake McConnell: paleogeography, age, duration, and associated river deltas, Mackenzie River Basin, Western Canada. Quaternary Science Reviews 13, 829-843. doi: 10.1016/0277-3791(94)90004-3

Stephenson, S.R., Smith, L.C., Agnew, J.A., 2011. Divergent long-term trajectories of human access to the Arctic. Nature Climate Change 1, 156-160. doi: $10.1038 /$ nclimate 1120

Stuiver, M., 1975. Climate versus changes in 13C content of the organic components of lake sediments during the late Quaternary. Quaternary Research 5, 251-262. doi: 10.1016/0033-5894(75)90027-7

Stuiver, M., Polach, H.A., 1977. Discussion: reporting of 14C data. Radiocarbon 19, $355-363$.

Stuiver, M., Reimer, P.J., 1993. Extended 14C database and revised Calib 3.0 14C age calibration program. Radiocarbon 35, 215-230. 
1055 Terasmaa, J., 2011. Lake basin development in the Holocene and its impact on the 1056 sedimentation dynamics in a small lake (southern Estonia). Estonian Journal of Earth 1057 Sciences, 60(3), 159-171. doi: 10.3176/earth.2011.3.04

1058

1059

1060

1061

1062

1063

1064

1065

1066

1067

1068

1069

1070

1071

1072

1073

1074

1075

1076

1077

1078

1079

1080

1081

1082 Wright Jr., R.G., Mann, D.H., Glaser, P.H., 1984. Piston cores for peat and lake

1083

1084

Thomas, E.K., Briner, J.P., Axford, Y., Francis, D.R., Miller, G.H., Walker, I.R., 2011. A 2000-yr-long multi-proxy lacustrine record from central Baffin Island, Arctic Canada reveals first millennium AD cold period. Quaternary Research 75, 491-500. doi: 10.1016/j.yqres.2011.03.003

Upiter, L.M., Vermaire, J.C., Patterson, R.T., Crann, C., Galloway, J.M., Macumber, A.L., Neville, L.A., Swindles, G.T., Falck, H., Roe, H.M., Pisaric, M.F.J., in review. A mid- to late Holocene chironomid-inferred temperature reconstruction for the central Northwest Territories, Canada. Journal of Paleolimnology.

Webb, R.S., Webb, T., 1988. Rates of sediment accumulation in pollen cores from small lakes and mires of eastern North America. Quaternary Research 30, 284-297. doi: 10.1016/0033-5894(88)90004-X

Wedel, J.H., Smart, A., Squires, P., 1990. An overview study of the Yellowknife river basin, N.W.T. N.W.T. programs: inland waters directorate conservation and protection. Western and Northern Region, Environment Canada, Ottawa.

Wolfe, B.B., Edwards, T.W.D., Aravena, R., MacDonald, G.M., 1996. Rapid Holocene hydrologic change along boreal tree-line revealed by $\delta 13 \mathrm{C}$ and $\delta 18 \mathrm{O}$ in organic lake sediments, Northwest Territories, Canada. Journal of Paleolimnology 15, 171-181. doi: 10.1007/BF00196779 sediments. Ecology 65, 657-659. doi: 10.2307/1941430 
1085 a) Waite Lake

1086

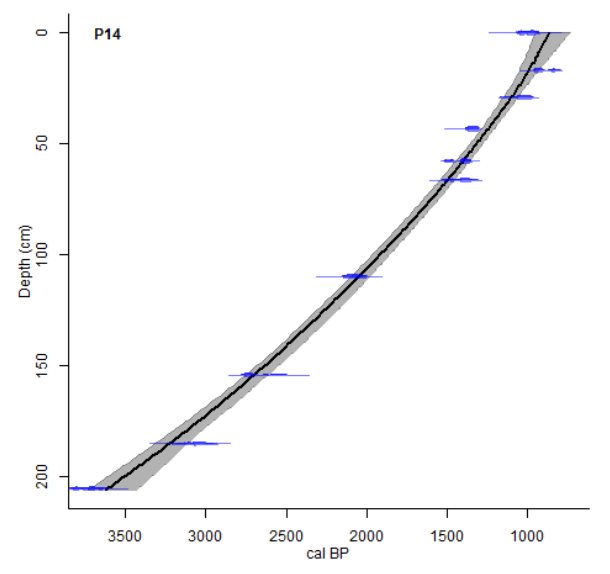

1087

b) Danny's Lake

1088

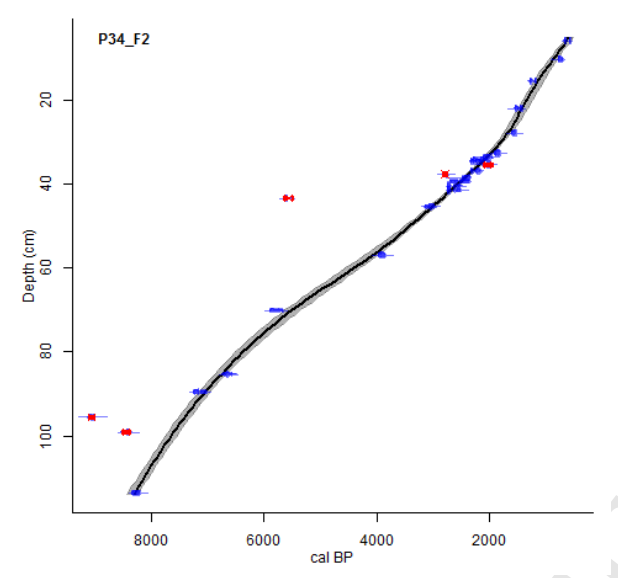

1089

c) Horseshoe Lake

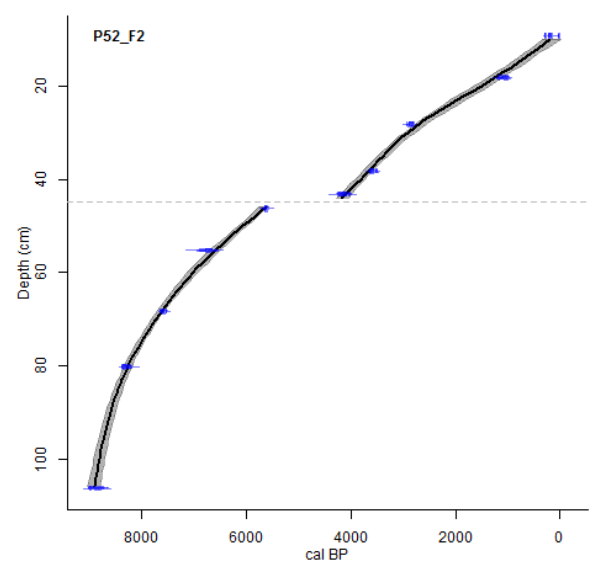

1091 Supplementary Figure 1. Smooth spline age-depth model constructed for: a) Waite 1092 Lake; b) Danny's Lake; and c) Horseshoe Lake using the age-depth modeling software 1093 Clam and the IntCal13 calibration curve. For Horseshoe Lake, a hiatus is shown with a 1094 dashed line at $45 \mathrm{~cm}$ 